ZatącZnils

DOI 10.21697/zk.2020.7.30

\title{
KERAUNOS. PRZYCZYNEK DO HISTORII PEWNEGO WYOBRAŻENIA RELIGIJNEGO*
}

HERMANN USENER

Uczniom i przyjaciołom z wdzięczną pamięcią, 23 X 1904

W roku 1868 Paul Foucart odkrył w Mantinei z grubsza obrobiony blok wapienny, na którym widniał napis: „ $\triangle \mathrm{IO} \Sigma \mid \mathrm{KEPAYNO”[Zeusowi} \mathrm{Piorunowi],}$ najwyraźniej służący do oddzielenia świętego miejsca trafionego piorunem od świata profanum. Opublikowanie przez odkrywcę napisu w roku 1875 wzbudziło żywe zainteresowanie, a Henri Weil poświęcił mu nawet osobne omówienie ${ }^{1}$. Wobec doskonałego stanu zachowania napisu należało wykluczyć hipotezę, że brakuje w nim litery „I”; trzeba było więc przyjąć, że rzeczywiście chodzi o formułę: „Zev̀s Kepavvóc” [Zeus Piorun]. Stało się to pierwszym wyłomem w dominujących poglądach na temat greckiej mitologii i wyobrażeń religijnych. To nowe odkrycie posiada wyjątkowe znaczenie również dlatego, że pozwala nam zajrzeć we wszystkie istotne

* Podstawa przekładu: Hermann Usener, Keraunos. Ein Beitrag religiöser Begriffsgeschichte, Bonn 1904. Redaktor przekładu wyraża wdzięczność Marcinowi Beściakowi, Dominice Budzanowskiej-Weglendzie oraz Wojciechowi Wrotkowskiemu za konsultacje polskich tłumaczeń cytatów greckich i łacińskich. Wszystkie wtrącenia w nawiasach kwadratowych oraz przypisy oznaczone odpowiednią adnotacją pochodzą od redaktora przekładu.

1 P. Foucart, Le Zeus Keraunos de Mantinée, „Monuments grecs publiés par l'Association pour l'encouragement des études grecques en France" 1875, vol. 1, nr 4, s. 23-26; Ph. Le Bas, P. Foucart, Explication des inscriptions grecques et latines recueillies en Grèce et en Asie Mineure II, Paris 1847, nr 352a, s. 209; Inscriptiones graecae antiquissimae praeter Atticas in Attica repertas, hrsg. von H. Roehl, Berlin 1882, s. 36; por. H. Weil, Zeus Keraunos, „Revue archéologique” 1876, vol. 32, s. 50-51. 
etapy ewolucji wyobrażenia, którego dotyczy napis. Skłoniło mnie to do omówienia tutaj tego zagadnienia w szerszym kontekście, choć najistotniejsze uwagi poczyniłem już w innym miejscu ${ }^{2}$.

Gdyby w Mantinei chodziło tylko o zawężenie złożonego wyobrażenia Zeusa, to można byłoby tego dokonać, używając jedynie epitetu przymiotnikowego, takiego jak „Kepaúvı ৎ” [Piorunowy]. Już sam językowy aspekt zagadnienia zmusza nas do przyjęcia, że oddawano cześć również Keraunosowi [Piorunowi] jako boskiej personifikacji. Jedynie pod warunkiem, że takie wyobrażenie istotnie występowało w kulcie i było rozpowszechnione, można by je - poprzez podporządkowanie - połączyć z nazwą złożonego bóstwa uranicznego. Jeśli taki wniosek kogoś nie przekonuje, to niech sam spróbuje pogodzić ze sobą fakty.

\section{1.}

Już Henri Weil był na właściwym tropie, gdy przytoczył zachowany we fragmencie dzieła Chryzypa ustęp z Teogonii Hezjoda, w którym o Zeusie i zapłodnionej przez niego Metis czytamy3:

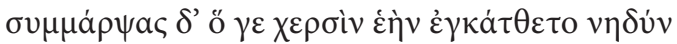

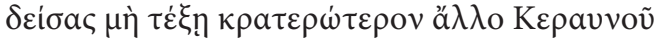

[pochwyciwszy zaś ją rękoma, umieścił ją w swym brzuchu, lękając się, by nie zrodziła czegoś jeszcze potężniejszego niż piorun (= od keraunosa)]

i w Kepavvoṽ [„(od) keraunosa”] rozpoznał imię własne. Zeus obawiał się, że Metis mogłaby wydać na świat trzecią istotę, przewyższającą jeszcze Keraunosa. Keraunos jawi się więc tu jako najsilniejsza obok Zeusa istota boska, całkowicie odrębna od niego jako niezależny bóg.

2 H. Usener, Götternamen. Versuch einer Lehre von der religiösen Begriffsbildung, Bonn 1896.

3 Cyt. za: C. Galeni, De placitis Hippocratis et Platonis libri novem, ed. I. Mueller, t. 1: Prolegomena critica, textum graecum, adnotationem criticam versionemque latinam continens, Lipsiae 1874, III, 8, s. 320; por. H. Usener, Eine Hesiodische Dichtung, „Rheinisches Museum für Philologie” 1901, vol. 56, s. 174-186 [= Kleine Schriften, t. 3, Leipzig-Berlin 1914, s. 176-187]. 
Taki motyw, tutaj związany z Zeusem, powraca w opowieści o Tetydzie, o której rękę ubiegali się dwaj synowie Kronosa: Zeus i Posejdon. W Ósmej Odzie Istmijskiej na cześć zwycięstwa Kleandrosa z Ajginy Pindar pisze (Isthm., VIII, 32-35):

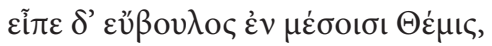

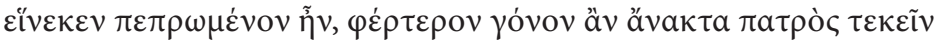

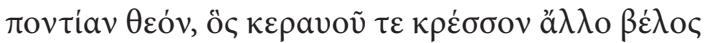

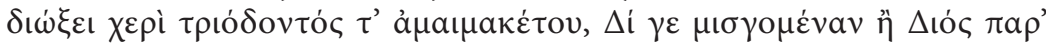
ả $\delta \varepsilon \lambda \varphi \varepsilon \circ \tilde{\sigma} \sigma \mathrm{t} v$.

[Dobrze rządząca Temida między nimi rzekła,

Że z przeznaczenia ta morska bogini

Syna ma wydać dzielniejszego od ojca;

Ma on pociskiem ciskać $\mathrm{z}$ rąk innym

lepiej niż piorunem czy strasznym trójzębem,

Gdyby się z Zeusem złączyła

czy którymś z jego braci ${ }^{4}$.]

Również Ajschylos każe Prometeuszowi odgrażać się w niejasnej dla nas uwadze dotyczącej przyszłości Zeusa (Prometh., 920-925):

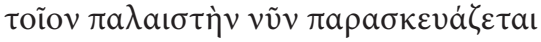

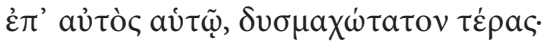

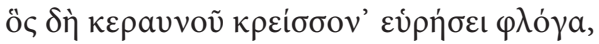

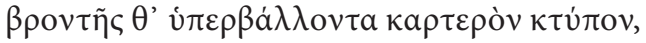

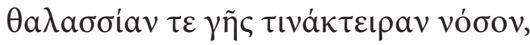

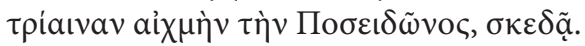

[Takiego rywala teraz przygotowuje

sam przeciwko sobie, niezwalczone dziwo;

on zaiste silniejszy od pioruna odkryje płomień

i huk potężny, straszliwszy od grzmotu

4 Tłumaczenie polskie według: Pindar, Ody zwycięskie: olimpijskie, pytyjskie, nemejskie, istmijskie, tłum. M. Brożek, Kraków 1987, s. 65 (przyp. red.). 
i morską udrękę wstrząsającą ziemię,

trójząb, włócznię Posejdona, rozproszy.] ${ }^{5}$

Porównanie tych dwóch miejsc jest nader pouczające. Dla poetów z V wieku [przed Chrystusem] Keraunos nie mógł być już, jak w przypadku starego pieśniarza z Beocji [tj. Hezjoda], istotą osobową: dla nich błysk pioruna jest jedynie bronią ( $\beta \dot{c} \lambda$ oৎ [„pocisk”] - u Pindara) albo „płomieniem” ( $\varphi \lambda$ ó $\xi$ - u Ajschylosa) Zeusa.

Heraklit nazwał „piorunem” boski ogień, w którym dostrzegał osta-

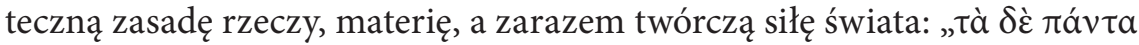

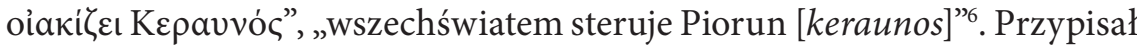
mu zatem działanie bytu osobowego. Można zrozumieć motywy, dla których wybrał właśnie to określenie. Poprzez jedno słowo chciał połączyć oba aspekty swojego pierwotnego żywiołu ognia - materialny i duchowy: zwyczajny „ogień” ( $\pi \tilde{u} \rho$ ) uzyskał dla niego, według tej koncepcji, aspekt duchowy jako określenie Zeusa i - co w innym miejscu przyjmuje jedynie z zastrzeżeniem - uwolnił go od aspektu materialnego ${ }^{7}$. Skoro Heraklit mógł posłużyć się tym śmiałym określeniem, to oznacza, że dla niego zarówno boskie, jak i osobowe znaczenie pojęcia keraunos wciąż jeszcze było naturalne. Tak jednak już nie było, gdy szkoła stoicka włączyła doktrynę Heraklita do własnej filozofii przyrody. Warto się więc przyjrzeć, jak stoicy

${ }^{5}$ Por. istniejące polskie tłumaczenie: Prometeusz w okowach, [w:] Ajschylos, Tragedie, tłum. S. Srebrny, Kraków 2005, s. 225: „[...] takiego przeciw sobie sam gotuje ninie / zapaśnika, przemożne, niezwalczone dziwo! / Ów ogniem razić będzie od piorunowego / mocniejszym, a grzmieć będzie groźniej niżli grom. Oszczepem I - ziemiotrzęsem o takiej władać będzie sile, że rozbije nim w drzazgi trójząb Posejdona!" (przyp. red.).

${ }^{6}$ Heraklit, Fr. 28 według wydania: Heracliti Ephesii Reliquiae, ed. I. Bywater, Oxford 1877, s. 12 [= Heraklit, Fr. 64 według Die Fragmente der Vorsokratiker, griechisch und deutsch, hrsg. von H. Diels, Berlin 1903, s. 75-76]; fragment znany z cytatu zachowanego u Hipolita Rzymskiego: Hippolytus, Origenis Philosophumena sive Omnium haeresium refutatio, IX, 10, 31 M, ed. E. Miller, Oxford 1851, s. 283.

7 Heraklit, Fr. 65 (ed. Bywater, op. cit., s. 26) = Heraklit, Fr. 32 D (ed. Diels, op. cit., s. 72); por. J. Bernays, Neue Bruchstücke des Heraklit von Ephesus, [w:] idem, Gesammelte Abhandlungen, hrsg. von H. Usener, Berlin 1884, s. 89 i n. 
poradzili sobie z przejętym pojęciem keraunos. Kleantes w tych oto słowach z Hymnu do Zeusa ${ }^{8}$ :

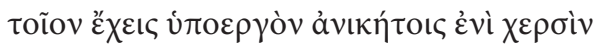

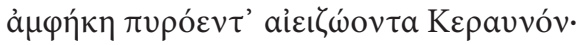

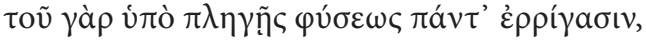

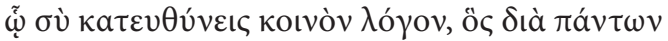

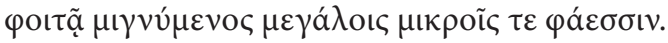

[Takiego sługę masz w rękach niezwyciężonych

obosieczny, ognisty, wiecznie żywy Piorun (keraunos):

bo pod jego ciosem wszystkie [rzeczy] natury się wzdrygają,

Ty nim prostujesz wspólny rozum (logos), który przez wszystko

przenika, mieszając się z wielkimi i małymi światłami.]

ściśle nawiązał do Heraklita i przejął keraunosa wraz z całą jego aktywno-

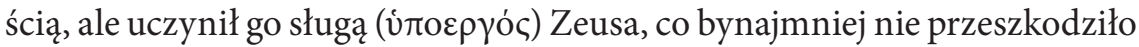
$\mathrm{w}$ jego materialnym pojmowaniu, odkąd alegoryczna interpretacja postaci bogów zyskała na popularności. Nie wydaje się jednak, by pierwotna koncepcja Heraklita całkiem zanikła u stoików: na monetach Antoninusa Piusa ukazany został skrzydlaty znak pioruna opatrzony napisem Providentia[e] deorum [„Opatrzności bogów”] (il. 1) ${ }^{10}$ : piorun jest więc widzialnym obrazem Opatrzności, która „steruje wszechświatem”.

8 Ioannis Stobaei, Anthologii libri duo priores qui inscribi solent Eclogae physicae et ethicae, I,1,12, hrsg. von C. Wachsmuth, t. 1, Berlin 1884, s. 25-26; por. R. Hirzel, Untersuchungen zu Cicero's philosophischen Schriften, t. 2: De finibus, De officiis, Leipzig 1882, s. 118 i n.

9 H. Cohen, Description historique des monnaies frappées sous l'Empire Romain, communément appelées médailles impériales, $2^{\mathrm{e}}$ éd., t. 2, Paris - Londres 1882, s. 338, nr 678-685 (z ilustracją).

${ }_{10}$ Artykuł Hermanna Usenera nie zawiera materiału ilustracyjnego. Do polskiej edycji katalog monet opracowała i skorelowała $\mathrm{z}$ tekstem mgr Małgorzata Krawczyk (przyp. red.). 

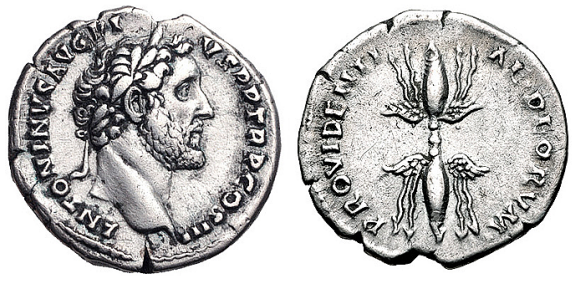

Il. 1. Antoninus Pius, denar (Rzym), 140-43 r. Awers: ANTONINVS AVG PI-VS P P TR P COS III; głowa cesarza $z$ broda, $w$ wieńcu laurowym, w prawo. Rewers: PROVIDENTI-AE DEORVM; uskrzydlony piorun

Orficki Hymn do Zeusa jako boga burzy (Orph. Hymn. XIX) nosi we wszystkich rękopisach nagłówek Kepavvoũ. Wydawcy, wśród nich jeszcze Eugen Abel, bez wahania wprowadzali tu lekcję Kepavvíou $\Delta$ ióc [Piorunowego Zeusa]. Albrecht Dieterich słusznie jednak opowiedział się za wersją przekazaną w rękopisach ${ }^{11}$. Pozorną sprzeczność między nagłówkiem Kepavvoũ i treścią hymnu, który jest w istocie skierowany do Zeusa, można szybko i łatwo rozwiązać. Istnieją źródła, które, choć enigmatyczne i rozproszone, w pełni wystarczają, aby stwierdzić, że aż do późnego VI wieku wśród Greków powszechny był kult Keraunosa jako bóstwa. Nie jest więc niczym dziwnym, że lud, który oddzielił się od helleńskiego szczepu jeszcze przed jego wkroczeniem na arenę dziejów, zachował aż do znacznie późniejszych czasów kult Keraunosa, który zakorzenił się tam głębiej w trakcie długiego życia w izolacji. Mowa tu o Macedończykach. Tradycja podaje, że Seleukos I Nikator przy zakładaniu Seleucji Nadmorskiej (Seleucia Pieria) ustanowił w tym mieście kult Keraunosa: „po dziś dzień - dodaje Appian - mają zwyczaj składania mu ofiar i śpiewania hymnów”12. Pewna inskrypcja z Seleucji (CIG 4458)

11 A. Dieterich, De hymnis Orphicis capitula quinque: ad veniam legendi in Universitate Philippina Marpurgensi a philosophorum ordine impetrandam, Marburg 1891, s. 19, 1 [por. nowsze wydanie hymnów orfickich i polskie tłumaczenie: G. Riccardelli, Inni Orfici, Milano 2000; wyd. pol. Hymny orfickie, tłum. i oprac. E. Żybert, Wrocław 2012, s. 71-72 (przyp. red.)].

${ }_{12}$ Appiani Alexandrini Romanarum historiarum XI, 58 (299) (por. wydanie: Appian's Roman History, vol. 1-3, ed. and transl. by H. White, London - New York

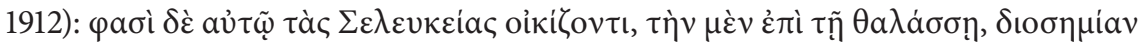

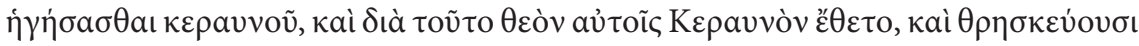

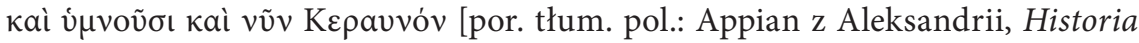
rzymska, t. 2, tłum., oprac. i wstęp L. Piotrowicz, Wrocław - Warszawa 2004 (cop.), s. 451-452: „Podobno przy założeniu obu Seleucji kierował się znakami z nieba, 


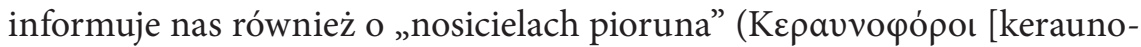
forowie]), którzy byli kapłanami zmieniającymi się co roku. Także monety potwierdzają i uzupełniają świadectwo Appiana. W czasach królewskich [tj. w okresie Seleukidów: 312-63 p.n.e.] noszą one zazwyczaj na awersie głowę Zeusa w wieńcu laurowym, na rewersie zaś zwykły albo uskrzydlony piorun (il. 2). Jednak już pod koniec tej epoki pojawiają się przedstawienia, które wyraźnie ukazują piorun jako bezpośredni obiekt czci: za czasów Antiocha VIII Gryposa (121-96) - uskrzydlony piorun otoczony szeroką wstęgą; za czasów Demetriusza III (95-88) oprócz takiego wizerunku bywał na monetach przedstawiany również potężny, skrzydlaty piorun, leżący na niskim krześle [kurulnym] (Stuhl) (il. 3) ${ }^{13}$. Na brązowej monecie Antiocha XI Epifanesa piorun spoczywa na trójnogu, a z lewej strony zdaje się zwisać związana supłem przepaska (taenia) ${ }^{14}$. Później Keraunos pojawiał się często na emisjach z czasów autonomicznej administracji i z okresu cesarstwa, gdzie był ukazywany na poduszce leżącej na świętym krześle, a z obu jego stron zwisała wstęga (il. 4) ${ }^{15}$. Nie sposób zaprzeczyć, że na późniejszych

a mianowicie przy Seleucji nad morzem piorunem, stąd mieszkańcom tego miasta dał piorun jako bóstwo opiekuńcze; toteż do dziś dnia czczą i sławią w hymnach piorun" (przyp. red.)].

13 Antioch VIII: P. Gardner, Catalogue of the Greek Coins in the British Museum: The Seleucid Kings of Syria, London 1878, tabl. XXIV, fig. 6; por. s. 90. Demetriusz III: ibidem, tabl. XXVI, fig. 11; por. s. 101; drugie przedstawienie w: E. Babelon, Catalogue des monnaies grecques de la Bibliothèque nationale, Les rois de Syrie, d'Arménie, et de Commagène, Paris 1890, tabl. XXVIII, fig. 5; por. s. 207, nr 1571-1573 (gdzie krzesło zostało błędnie określone jako ołtarz), według Babelona wybite w Seleucji, s. CLXXI.

${ }_{14}$ P. Gardner, op. cit., tabl. XXVI, fig. 7; por. s. 99, nr 13. Słabo zachowany egzemplarz z kolekcji paryskiej Babelon przypisał Antiochowi VIII Gryposowi (op. cit., s. 188, tabl. XXV, fig. 12).

15 J.H. Eckhel, Doctrina numorum veterum, Pars I: De numis urbium, populorum, regum, vol. 3: Continens reliquam Asiam Minorem, et regiones deinceps in ortum sitas, $2^{\mathrm{e}}$ éd., Wien 1828, s. 326 (Seleucja Pieria: typ fulmen super mensa według Eckhela); B.V. Head, Historia Numorum. A Manual of Greek Numismatics, Oxford 1887, s. 661; W. Wroth, Catalogue of the Greek Coins in the British Museum: Galatia, Cappadocia, and Syria, London 1899, s. LXXII i n., 269 i n., z ilustracjami na tablicach: XXXII, fig. 6-8, 10; XXXIII, fig. 2, 6. 


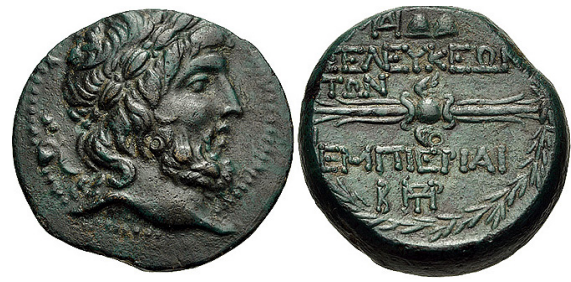

Il. 2. Moneta brazowa (Seleucja Pieria, Syria), 200-101 r. p.n.e. Awers: głowa Zeusa w wieńcu laurowym w prawo. Rewers: $\Sigma E \Lambda E Y K E \Omega N /$ $T \Omega N$ / EM MIEPIAI; uskrzydlony piorun; nad legenda monogram i dwa pileusy; poniżej B i monogram; całość wewnątrz wieńca laurowego

monetach, począwszy od końca epoki królewskiej, ukazywano piorun jako przedmiot, któremu oddawano cześć: wstęga i przepaska są bowiem oznakami świętości. I na odwrót - monety z epoki królewskiej ukazują piorun jako atrybut Zeusa: staromacedoński Keraunos mógł być pojmowany przez ludność grecką jedynie jako znak i symbol boga burzy; dlatego też Keraunosa mimowolnie zastąpił Zzùc Kepaúvıoৎ [Zeus Piorunowy] - na monetach Karakalli (il. 5) ${ }^{16}$ piorun nosi podpis „Zqù

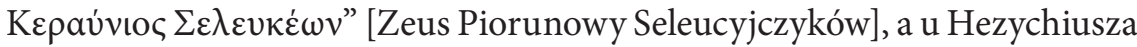

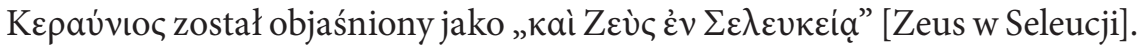

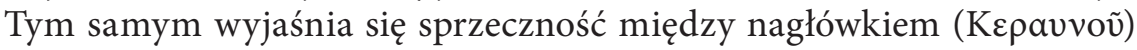
i treścią XIX Hymnu Orfickiego (jw.): hymn ten, jeśli nie większa część całego zbioru w ogóle, musiał powstać właśnie w takim miejscu jak Seleucja, gdzie stary kult Keraunosa stawiał opór religii ogólnogreckiej. Bez wątpienia jednak i w późniejszej epoce Seleucja nie była jedynym miejscem, w którym przetrwał kult Keraunosa w prastarej formie. Światło, jakie seleukidzkie monety rzucają na przekaz historyczny, prowadzi nas bowiem dalej.

Cześć oddawaną Keraunosowi można jeszcze wyraźniej dostrzec na monetach z Diocezarei w Cylicji ${ }^{17}$. O ile na monecie Trajana ukazany został

${ }^{16}$ J.H. Eckhel, op. cit, s. 326.

17 Trajan: F. Imhoof-Blumer, Kleinasiatische Münzen, Bd. 2, Wien 1902, s. 439, nr 3; Faustyna Młodsza: V. Langlois, Numismatique cilicienne. Lettre à M. F. de Saulcy sur des médailles inédites ou peu connues de la Cilicie. Premier article, „Revue Numismatique” 1854, s. 15; A. Loebbecke, Griechische Münzen aus meiner Sammlung II, „Zeitschrift für Numismatik” 1885, Bd. 12, s. 331; odwzorowane w: G.F. Hill, Catalogue of the Greek Coins in the British Museum: Lycaonia, Isauria, and Cilicia, London 1900, tabl. XII, fig. 13. Monety: Julii Domny (T.E. Mionnet, Description de médailles antiques, grecques et romaines, avec leur degré de rareté et leur estimation, t. 3, Paris 1808, s. 577, nr 195, odwzorowane w: G.F. Hill, op. cit., 

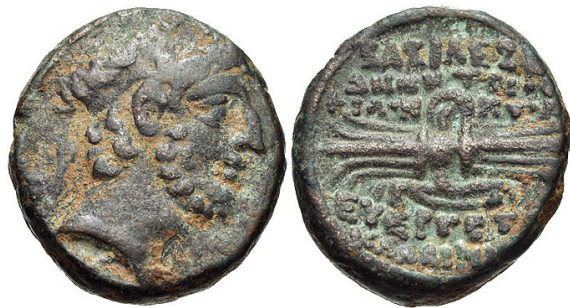

Il. 3. Demetriusz III Filopator, moneta brazowa (Seleucja Pieria, Syria), 95-88 r. p.n.e. Awers: głowa władcy $w$ diademie $w$ prawo.

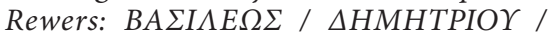

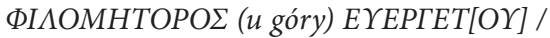

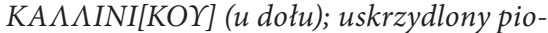
run na niskim krześle (tronie); w prawym polu $K$

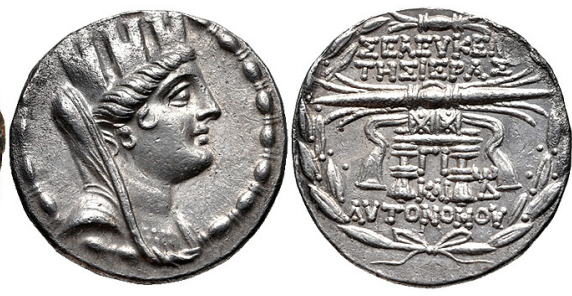

Il. 4. Srebrna tetradrachma (Seleucja Pieria, Syria), 97/96 r. p.n.e. (13 r. ery autonomii Seleucji). Awers: popiersie Tyche $w$ corona muralis, welonie, kolczyku i naszyjniku, w prawo. Rewers: $\Sigma E \Lambda E Y K E[\Omega N] / T H \Sigma$ IEPA $\Sigma$ (u góry) KAI / AYTONOMOY (u dotu); piorun przewiazany wstega na poduszce umieszczonej na krześle (tronie); poniżej ГI (data); w prawym polu monogram; całość wewnątrz wieńca laurowego
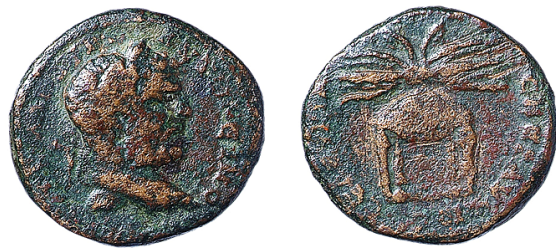

Il. 5. Karakalla, moneta brązowa (Seleucja Pieria, Syria), 211-17 r. Awers: [- - ] M AYP ANTSNEINOC [- - -]; głowa cesarza $z$ broda, $w$ wieńcu laurowym, w prawo. Rewers: [ZEY] C KEPAYNIOC CEAEYK[ESN]; duży piorun Zeusa Kerauniosa spoczywający na krześle (tronie) dawanej niewidzialnemu bóstwu wyobrażanemu na tronie do czci oddawanej jego przedstawieniu.

Warto zwrócić uwagę, że obydwa przedstawienia Keraunosa - zarówno na prostym krześle, jak i na uroczystym tronie - zostały tymczasowo przejęte przez emisje rzymskie. Jedna z wybitych przez Trajana monet restytucyjnych prezentuje na awersie popiersie divus Vespasianus, na rewersie zaś

tabl. XIII, fig. 1; por. s. 73, nr 9) i Filipa II Młodszego (T.E. Mionnet, op. cit., nr 197) widziałem w zbiorze F. Imhoof-Blumera. 

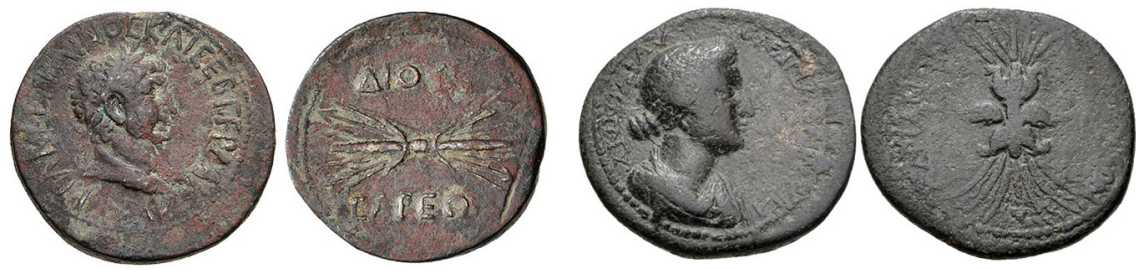

Il. 6. Trajan, moneta brazowa (Diocezarea, Cylicja), 98-117 r. Awers: [AYTO]KPA NEP TPAINOC (sic!) KAI CEB ГEP $\triangle A K[I]$; głowa cesarza $w$ wieńcu laurowym $w$ prawo. Rewers: $\triangle I O K[A I]-C A P E \Omega[N]$; piorun

Il. 7. Faustyna Młodsza, moneta brazowa (Diocezarea, Cylicja), 161-75 r. Awers: ANNIA ФAY-CTEINA [CEBAC] $\mathrm{TH}$; popiersie cesarzowej $w$ udrapowanej szacie w prawo. Rewers: [A $\triangle P I A N O N$ $\triangle I O K A I C A P E \Omega N]$ (legenda nieczytelna); uskrzydlony piorun

widnieje uskrzydlony piorun na przykrytym tronie (il. 9) $)^{18}$ : takim stemplem [menniczym] musiał się zatem posługiwać Wespazjan. Podobne przedstawienie widnieje na wybitej na nowo przez Trajana złotej monecie Tytusa (il. 10). Piorun na tronie ukazują również złote i srebrne monety Tytusa (il. 11) i Domicjana z lat 80-82 (il. 12) ${ }^{19}$. Jeszcze za czasów Antoninusa Piusa (cos. IIII [konsul po raz czwarty], a więc $145-165 \mathrm{r}^{20}$ ) przedstawiano piorun (bez skrzydeł) na tronie przykrytym płaszczem z frędzlami (il. 13) ${ }^{21}$.

${ }^{18} \mathrm{H}$. Cohen, Description historique des monnaies frappées sous l'Empire Romain, communément appelées médailles impériales, $2^{\mathrm{e}}$ éd., t. 1, Paris-Londres 1880, s. 419, nr 650; odwzorowania w: Collection de M. le Vicomte de Ponton d'Amécourt. Monnaies d'or romaines et byzantines, Paris 1887, tabl. VI, fig. 149. Moneta restytucyjna z awersem divus Titus w: H. Cohen, op. cit., t. 1, s. 462, nr 403.

19 Tytus: H. Cohen, op. cit, t. 1, s. 455, nr 314-316 (piorun, najczęściej uskrzydlony); Domicjan: ibidem, t. 1, s. 475, nr 61 i n.; s. 517, nr 554 z roku 80; s. 518, nr 574 i n. $\mathrm{z}$ roku 81; s. 519, $\mathrm{nr} 597 \mathrm{z}$ roku 82.

20 Objęcie czwartego (ostatniego znanego nam) konsulatu przez Antoninusa Piusa poświadczone jest dla 144/145 r. (consul designatus IV - wiosna [?] 144 r.; consul -1-13 stycznia [?] 145 r.), zob. D. Kienast, Römische Kaisertabelle. Grundzüe einer röischen Kaiserchronologie, Darmstadt 2004, s. 134 (przyp. red.).

${ }^{21}$ H. Cohen, op. cit., t. 2, s. 304, nr 345. 

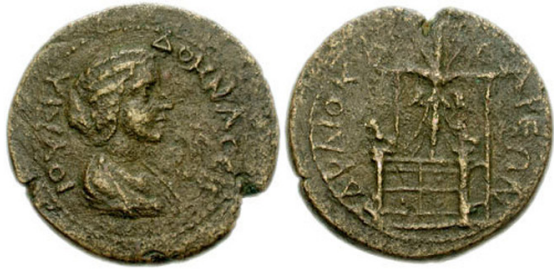

Il. 8. Julia Domna, moneta brazowa (Diocezarea, Cylicja), 193-217 r. Awers: IOYAIA $\triangle O M N A$ CEB; popiersie cesarzowej $w$ udrapowanej szacie $w$ prawo; $w$ prawym polu kontramarka w postaci orła. Rewers: A $\triangle P \triangle I O K A I C A P E \Omega N$; uskrzydlony piorun ustawiony pionowo na tronie z podłokietnikami w kształcie siedzących lwów
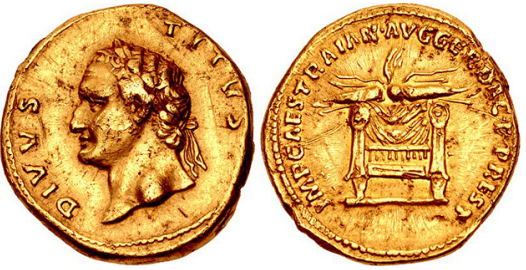

Il. 10. Restytucyjny aureus Tytusa wybity za panowania Trajana (Rzym), ok. 107 lub 112/13 r. Awers: DIVVS TITVS; głowa cesarza $w$ wieńcu laurowym $w$ lewo. Rewers: IMP CAES TRAIAN AVG GER DAC P P REST; uskrzydlony piorun na udrapowanym krześle (tronie)
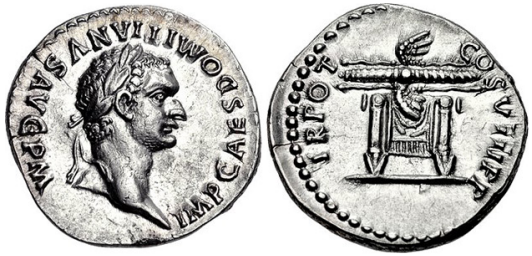

Il. 12. Domicjan, denar (Rzym), 82 r. Awers: IMP CAES DOMITIANVS AVG P M; głowa cesarza $z$ broda, $w$ wieńcu laurowym, w prawo. Rewers: TR POT COS VIII P P; uskrzydlony piorun na udrapowanym krześle (tronie)

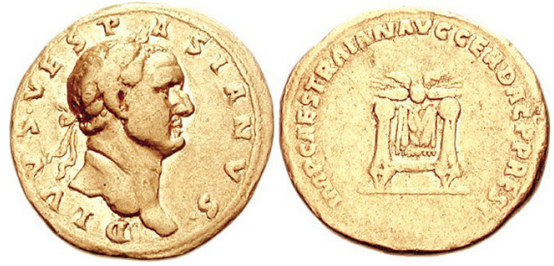

Il. 9. Restytucyjny aureus Wespazjana wybity za panowania Trajana (Rzym), $107 \mathrm{r}$. Awers: DIVVS VESPASIANVS; głowa cesarza $w$ wieńcu laurowym $w$ prawo. Rewers: IMP CAES TRAIAN AVG GER DAC P P REST; uskrzydlony piorun na udrapowanym krześle (tronie)
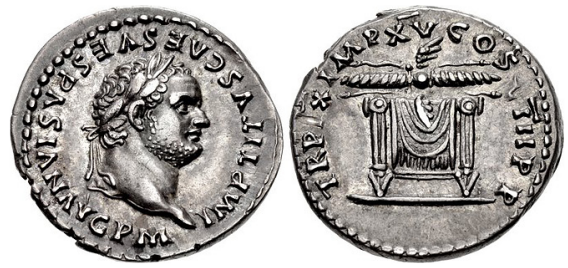

Il. 11. Tytus, denar (Rzym), 80 r. Awers: IMP TITVS CAES VESPASIAN AVG P M; głowa cesarza $z$ broda, $w$ wieńcu laurowym, w prawo. Rewers: TR P IX IMP XV COS VIII P P; uskrzydlony piorun na udrapowanym krześle (tronie)
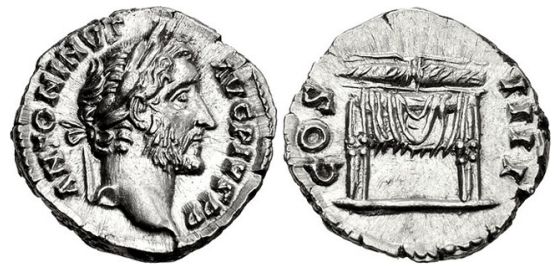

Il. 13. Antoninus Pius, denar (Rzym), 14561 r. Awers: ANTONINVS AVG PIVS P P; głowa cesarza z broda, $w$ wieńcu laurowym, w prawo. Rewers: COS IIII; piorun na udrapowanym krześle (tronie) 
Starannie wykonany relief z Mantui ${ }^{22}$ wskazuje nam, że takie przedstawienia monetarne również na Zachodzie miały jakieś zakorzenienie w kulcie: na pokrytym płaszczem tronie (albo łożu?) spoczywa ogromny piorun, o tron oparte jest berło, a po lewej stronie na ziemi pełni straż orzeł.

Trudno nie zgodzić się z przypuszczeniem, że stara macedońska forma kultu była rozpowszechniona także poza Syrią i Cylicją. Wśród licznych miast umieszczających na swoich monetach znak pioruna z pewnością były i takie, które trwały przy starych formach oddawania mu czci. Myślę, że są podstawy, by tak twierdzić, przynajmniej w odniesieniu do Aksos na Krecie. Niektóre ze srebrnych monet tego miasta ukazują na awersie głowę Zeusa $\mathrm{w}$ wieńcu laurowym, na rewersie zaś pięcioramienny piorun spoczywający na trójnogu (il. 14) ${ }^{23}$. Zarówno wiek monet, jak i fakt, że wielokrotnie w tym mieście wybijano na monetach trójnóg, a niekiedy także sam piorun, każą wykluczyć jakąkolwiek myśl o zapożyczeniu tego typu przedstawień z Syrii.

Granica terytorium, na którym Keraunos miał boskie poważanie, a którą wyżej musieliśmy początkowo nieco zawęzić, niespodziewanie, po uwzględnieniu tradycji macedońskiej, znacząco się poszerzyła. Pozostańmy przy Macedończykach, aby uzyskać dodatkowe, istotne potwierdzenie naszej tezy. Greckie nazwy własne w znacznie większym stopniu wiążą się z kultem, niż by to wynikało z powierzchownej obserwacji. Przy dokładniejszym zbadaniu wiele $\mathrm{z}$ tych nazw okazuje się dawnymi, z czasem zatartymi

${ }^{22}$ Ilustracje w: E. Braun, Vorschule der Kunstmythologie, Gotha 1854, tabl. VI; por. ibidem, s. 5 .

23 J.N. Svoronos, Numismatique de la Crète ancienne, accompagnée de l'histoire, la géographie et la mythologie de l'ile, Première partie: Description des monnaies, histoire et géographie, Mâcon 1890, tabl. III, fig. 10, 11; W. Wroth, Catalogue of the Greek Coins in the British Museum: Crete and the Aegean Islands, London 1886, tabl. III, fig. 12; por. ibidem, s. 14, nr 2. Prosty trójnóg na monetach z Aksos w: J.N. Svoronos, op. cit., tabl. III, fig. 1-4, 6-9; tabl. II, fig. 30-38; W. Wroth, op. cit., tabl. III, fig. 13-17; sam uskrzydlony piorun w: J.N. Svoronos, op. cit., tabl. III, fig. 5, 12, 13; W. Wroth, op. cit., tabl. III, fig.18 i n.; por. ibidem, s. 15, nr 12-16. W jednym przypadku (J.N. Svoronos, op. cit., tabl. III, fig. 1) rewers ma wielki trójnóg, a po lewej stronie na pustym polu - pięcioramienny piorun. 
określeniami bóstw lub herosów, które występowały w kulcie i w podaniach rodowych ${ }^{24}$. Również fakt, że imię boga Keraunosa funkcjonowało jako przydomek władców, należy uznać za niezbite świadectwo istnienia owego macedońskiego kultu. Przydomek „Keraunos” nosił Ptolemeusz [tj. Ptolemeusz Keraunos, 321-279 r. p.n.e.], po-
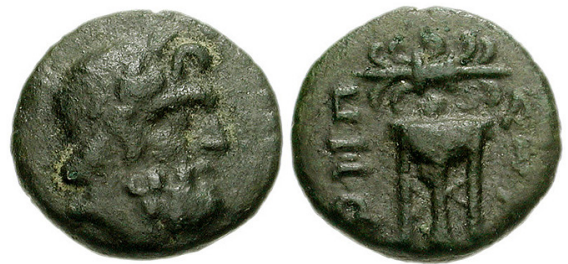

Il. 14. Moneta brązowa (Axos, Kreta), ok. 300-67 r. p.n.e. Awers: głowa Zeusa w wieńcu laurowym w prawo. Rewers: $C / A / E / I / \Omega / N$; piorun spoczywajacy na trójnogu chodzący z pierwszego małżeństwa Ptolemeusza I Sotera $\mathrm{z}$ Eurydyką ${ }^{25}$, który po życiu pełnym zawirowań poległ jako król Macedonii w bitwie przeciwko Celtom (279 r.). Podobnie starszy brat Antiocha III Wielkiego, Aleksander (Seleukos III), został przez żołnierzy nazwany Keraunosem ${ }^{26}$. Poeta Anaksippos stworzył komedię pt. Keraunos, jej bohaterem był pewien „pasożyt” - Damippos ${ }^{27}$ :

24 Zob. H. Usener, Götternamen, op. cit., s. 349 i n. Jako wyjaśnienie mogą

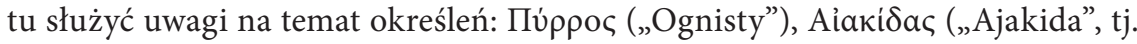
„potomek Ajakidesowy”), 'O $\rho \dot{\sigma} \tau\rceil \varsigma$ („Orestes”, tzn. „górski”) [w:] H. Usener, Heilige Handlung, „Archiv für Religionswissenschaft” 1904, Bd. 7, s. 330-333.

25 Appiani Alexandrini Romanarum historiarum XI, 62, 330.1-4; Pausanias, Graeciae descriptio, I,16,2 itd. [por. wydanie: Pausaniae Graeciae descriptio, hrsg. von M.H. da Rocha-Pereira, Bd. 1-3, Leipzig 1973-1981; por. wyd. pol.: Pauzaniasz, Wędrówka po Helladzie, t. 1: W świątyni i w micie, tłum. J. Niemirska-Pliszczyńska, oprac. B. Filarska, Wrocław 1973, s. 71 (przyp. red.)].

${ }^{26}$ Porfiriusz, Fr. 6, 11 według Fragmenta Historicorum Graecorum, ed. K. Müller, t. 3, Paris 1849, s. 710; w armeńskim przekładzie Kroniki Euzebiusza: Eusebii Chronicorum libri II, hrsg. von A. Schoene, t. 1, Berlin 1875, coll. 253, 10 [por. również: coll. 263, 7].

27 A. Meineke, Fragmenta Comicorum Graecorum, t. 4, Berlin 1841, s. 464 [= Athenaios, Deipnosophistes, X, 417 a]; na temat epoki zob. A. Meineke, Historia critica comicorum Graecorum, Berlin 1839, s. 469; por. wydanie Atenajosa: Athenaei Naucratitae Dipnosophistarum libri 15, ed. G. Keibel, Bd. 1-3, Leipzig 1887-1890 (Stuttgart 1985-1992) [wyd. pol.: Atenajos, Uczta mędrców, tłum. K. Bartol, J. Danielewicz, Poznań 2010, s. 778 (przyp. red.)]. 


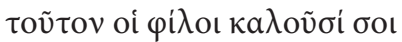

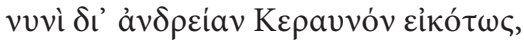

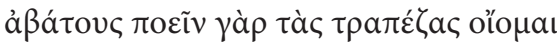

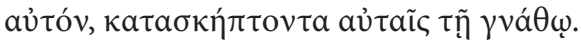

[(A.) (...) Zwą go przyjaciele dziś

Piorunem - za jego męstwo.

(B.) Oczywiście!

Czyni nieskalanymi ${ }^{28}$, wyobrażam sobie, stoły,

gdy na nie spadnie piorunem swej szczęki ${ }^{29}$.]

Biorąc pod uwagę czas powstania komedii, inspiracją dla tego dowcipnego konceptu mogła być dla autora postać Ptolemeusza Keraunosa. Znamy jednak jeszcze starszy wzorzec: Klearchos, słynny tyran Heraklei - którego to, że pobierał nauki u Izokratesa i Platona, nie uchroniło przed szaleństwem uznania się za boga - lubił przebierać się za Zeusa i nosić w ręku symbol błyskawicy, a swojemu synowi nadał imię Keraunos ${ }^{30}$. Zatem w megaryjskiej

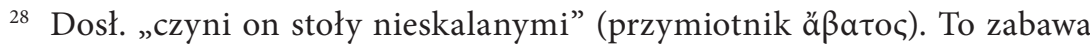
w skojarzenie $\mathrm{z}$ „oczyszczaniem” przez piorun miejsca, w które uderza: podobnie i Damippos oczyszcza, czyli „czyni nieskalanymi” zastawione stoły. Zabawą słowną jest również zastosowanie do opisu walenia szczęką w stoły czasownika

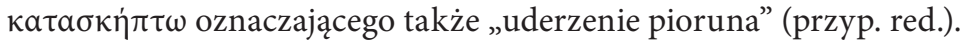

29 Tłumaczenie J. Danielewicza według: Atenajos, op. cit., s. 778 (przyp. red.).

30 Plutarch, De Fortuna Alexandri II 5, 338 b [por. wyd: Plutarch, Moralia, vol. 4: On the Fortune or Virtue of Alexander, transl. F.C. Babbit, Cambridge MA

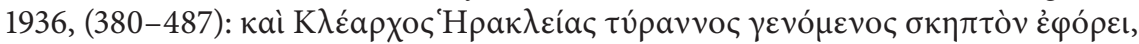

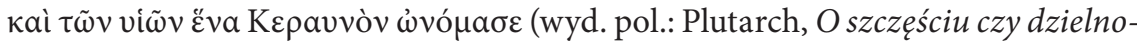
ści Aleksandra, tłum. i oprac. K. Nawotka, Wrocław 2003, s. 70: „[...] i Klearchos, tyran Heraklei, dzierżył berło (piorun) i jednemu ze swych synów dał na imię

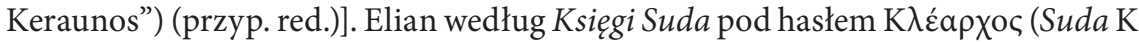
1714) [(por. wydanie Suidae lexicon, hrsg. von A. Adler, vol. 1-5, Leipzig 1928-1938 (1994-2001); w wersji zdigitalizowanej dostępne na: http://www.stoa.org/sol/): kaì

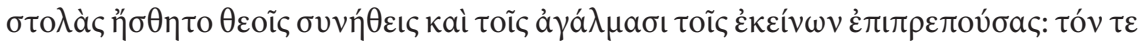

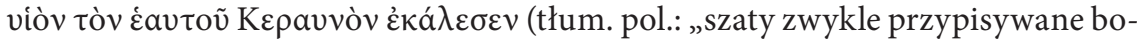
gom i stosowne do ich posągów zakładał, a także syna swego nazwał Keraunosem") (przyp. red.)]. Memnon u Focjusza, Biblioteka, 224. 222b, 15 [(por. wydanie: Photius,

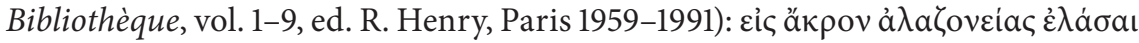


kolonii, daleko nad Morzem Czarnym, jeszcze w połowie IV w. p.n.e. żywe było wyobrażenie osobowego Keraunosa. Jest to kolejne potwierdzenie, że wstępnie zakreślone granice chronologiczne należy wyraźnie poszerzyć, przynajmniej w przypadku odległych terenów zamieszkałych przez ludność grecką.

\section{2 .}

Pewien obrzęd pokazuje, jak sobie wyobrażano boga Keraunosa. Dla Greków i Italików miejsce trafione piorunem było święte i nietykalne ${ }^{31}$. Bóstwo samo objęło je w posiadanie i w nim zamieszkało, dlatego też należało oddzielić je odpowiednim ogrodzeniem od świata profanum. Stąd wznoszono w takim

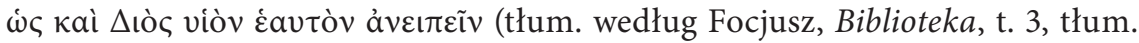
O. Jurewicz, Warszawa 1994, s. 38: „Doszedł do takiego szczytu zarozumialstwa, że sam ogłosił się synem Zeusa") (przyp. red.)].

31 Por. na przykład Festus Pauli, 91, 13 [por. to miejsce według wydania: Sexti Pompei Festi De verborum significatu quae supersunt cum Pauli epitome, hrsg. von W.M. Lindsay, Leipzig 1913 (1997), P 92 (65), 8-10: Fulguritum id quod est fulmine ictum, qui locus statim fieri putabatur religiosus, quod eum deus sibi dicasse videtur (tłum. pol.: „Fulguritum to miejsce uderzone piorunem, o którym sądzono, że od razu stało się święte, ponieważ wydaje się, że bóg je sobie przeznaczył”) (przyp. red.)]; Ammianus Marcellinus, Rerum Gestarum XXIII, 5, 13 [por. wydanie: Ammiani Marcellini Rervm gestarvm libri qui supersvnt, hg. von W. Seyfarth, Leipzig 1978: et hoc modo (scil. fulmine) contacta loca nec intueri nec calcari debere fulgurales pronuniant libri (tłum. pol. według: Ammianus Marcellinus, Dzieje rzymskie, t. 1, tłum., wstęp i przypisy I. Lewandowski, Warszawa 2001, na s. 451: „[...] Księgi wróżebnych piornuów mówią, że nie należy ani przyglądać się, ani chodzić po miejscu rażonym w ten sposób piorunami") (przyp. red.)]; Artemidor 2, 9, s. 93, 8, ed. R. Hercher (Artemidori Daldiani Onirocriticon libri V, Leipzig 1864) [por. wydanie: Artemidori Daldiani Onirocriticon libri V, hrsg. von R.A. Pack, Leipzig

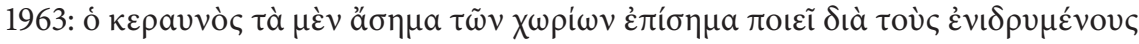

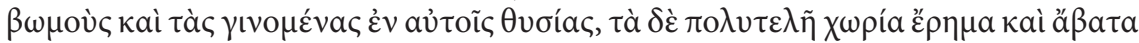

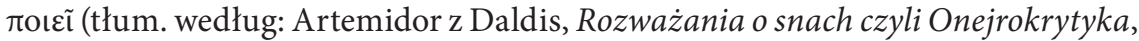
tłum. I. Żółtowska, Warszawa 1995, s. 104: „Gdy błyskawica niespodziewanie spadnie na ziemię w okolicy nikomu dotąd nie znanej, ołtarz wystawiony dla uczczenia tego faktu czyni ją sławną; uderzenie pioruna w uczęszczanym miejscu powoduje jego opustoszenie, bo nikt się nie waży tam przybywać”) (przyp. red.)]. 
miejscu ołtarz, na którym regularnie składano ofiary. Grecy nazywali takie

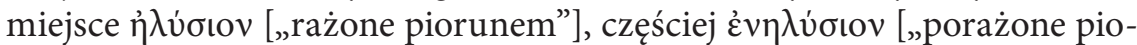

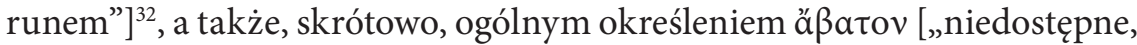
nietykalne”], Rzymianie - fulguritum [„uderzone piorunem”], bidental oraz, ze względu na formę ogrodzenia, puteal [tj. nadbudowa studni] ${ }^{33}$. Rzymski, a prawdopodobnie także powszechny zwyczaj pozwalał na upamiętnienie uderzenia pioruna jedynie pod gołym niebem: gdy piorun trafił w zadaszony budynek, to nad putealem trzeba było wykonać otwór w dachu.

Podobnie jak miejsce, tak i człowiek trafiony piorunem był uważany za istotę świętą ${ }^{34}$ : bóg uczynił sobie w nim mieszkanie. Dlatego „zaznaje czci niczym bóg” - jak czytamy w Rozważaniach o snach Artemidora z Daldis ${ }^{35}$.

32 Szczegóły: Polemonis Periegetae Fragmenta, hrsg. von L. Preller, Leipzig 1838 , s. 146 i n.

${ }^{33}$ Fulguritum - Festus Pauli, De verborum significatu s.v. Fulguritum [P 92 (65), 8-10], ibidem, s.v. bidental [P 33 (24), 17]; por. I. Casaubon w uwagach do Persjusza 2, 27, s. 192 i n., na temat słynnego puteal Scribonianum albo Libonis zob. Festus, De verborum significatu s.v. scribonianum, [P 333 (494), 34]; E. Babelon, Monnaies de la République Romaine, Paris 1885-1856, vol. 2, s. 427 i n. 584. Na temat wymogu gołego, niezakrytego nieba zob. Festus, De verborum significatu, P 333 (495), 4-5; Witruwiusz, De architectura I 2, 5 [por. wydanie: Vitruvii De architectura libri decem, hrsg. von F. Krohn, Leipzig 1912; oraz wyd. pol.: Witruwiusz, O architekturze ksiąg dziesięć, tłum. K. Kumaniecki, Warszawa 1956, s. 15 (przyp. red.)]; zob. poniżej, s. 656-657.

${ }^{34} \mathrm{Na}$ temat statusu osób, które zginęły od uderzenia pioruna, zob. również: A. Wypustek, Bogowie, herosi i wybrańcy. Wizerunek zmarlych w greckich epigramach nagrobnych epoki hellenistycznej i grecko-rzymskiej, Wrocław 2011, s. 304-319 (przyp. red.).

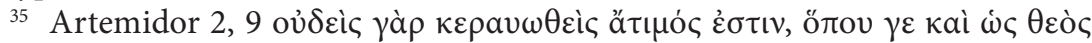

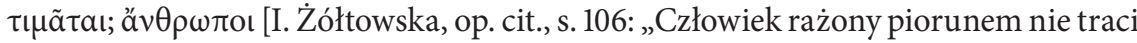
dobrego imienia; przeciwnie - kto wyszedł cało z takiej opresji, odbiera cześć niemal

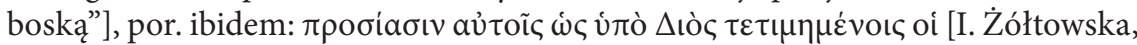
op. cit., s. 104: „(...) jak przystało na ludzi dotkniętych przez samego Zeusa (...)”]. Por. E. Rohde, Psyche: Seelencult und Unsterblichkeitsglaube der Griechen, t. 1, Leipzig 1898, s. 320 i n. [zob. pol. wyd.: Psyche. Kult duszy i wiara w nieśmiertelność starożytnych Greków, wyb. H. Eckstein, tłum. J. Korpanty, Warszawa 2007 (przyp. red.)]. 
O Zaratustrze opowiadano, że bóstwo, aby przyciągnąć do siebie jego duszę, nawiedziło go pod postacią pioruna: na tej podstawie autor Homilii pseudoklementyńskich twierdzi, że czymś powszechnym była cześć oddawana trafionym piorunem jako ulubieńcom bogów ${ }^{36}$. Wyobrażenie to czyni zrozumiałym zwyczaj kultowy mieszkańców Tarentu ${ }^{37}$. Przed wieloma domostwami w mieście ustawiono stele, będące pomnikami upamiętniającymi tych obywateli, którzy niegdyś dopuścili się przestępstw w mieście Japygów, Karbinie, i za karę wspólnie zostali porażeni piorunem. Rocznicy nieszczęśliwego wypadku nie obchodzono jednak żałobą i składaniem ofiar za

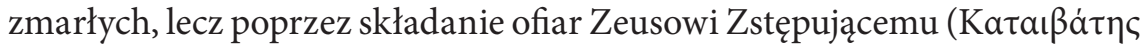
[Kataibates]). Nie przejmowano się tą wewnętrzną sprzecznością, że pioruny spadły na złoczyńców jako narzędzie boskiej kary - poprzez trafienie

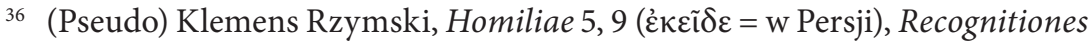
4, 28 (tutaj ogólnie) [por. wydanie: Die Pseudoklementinen (CGCS), t. 1: Homilien, hrsg. von B. Rehm, Berlin 1953 (rev. G. Stecker 1992); t. 2: Rekognitionen in Rufins Übersetzung, hrsg. von B. Rehm, Berlin 1965 (rev. G. Stecker 1994): hoc denique exemplo etiam nunc multi eos qui fulmine obierint sepulcris honoratos tamquam amicos dei colunt („Idąc za takim przykładem także i teraz wielu czci tych, którzy zginęli od pioruna, honorując ich grobowcami jako przyjaciół Boga") (przyp. red.)].

37 Klearchos według Fragmenta Historicorum Graecorum, ed. K. Müller, t. 2, Paris 1848, s. 306 [= Klearchos, Fr. 48 według Die Schule des Aristoteles, hrsg. von F. Wehrli, t. 3, Basel 1948 (przyp. red.)]; cytat zachowany w: Athen. Deipnosophistes, XII, 522 d-f [por. polskie tłumaczenie K. Bartol według: Atenajos, op. cit., s. 974-975: „Z kolei mieszkańcy Tarentu - mówi Klearchos w czwartej księdze Żywotów gdy osiągnęli wielkie wpływy i potęgę, tak bardzo zaczęli się pławić w luksusie, że utrzymywali całe ciała w stanie gładkości i zaszczepili pośród pozostałych narodów zwyczaj depilowania się. [...] Później, przez zbytek, skierowali się ku występkom, zburzyli Karbinę, miasto Japygów, i zebrawszy tamtejszych chłopów, dziewczęta i młode kobiety w świątyniach miasta urządzili widowisko: przez cały dzień wystawiali ich nagich na widok publiczny. [...] Tak wielki gniew zrodził się w bóstwach, że zabili piorunem wszystkich mieszkańców Tarentu, którzy dopuścili się zbrodni w Karbinie. Jeszcze i teraz przed każdym domem w Tarencie stoi tyle stel, ilu jego mieszkańców wyprawiło się do kraju Japygów. W rocznicę ich śmierci nie opłakują przy nich zmarłych ani nie składają zwyczajowych płynnych ofiar na ich cześć, lecz składają ofiary Zeusowi Miotającemu Gromy (Katabaitesowi)" (przyp. red.)]. 
piorunem owym Tarenteńczykom przypadł w udziale wyższy los, toteż nie godziło się wspominać ich jako zwyczajnych zmarłych. Jeszcze Cyryl Jerozolimski używa tego popularnego wyobrażenia ${ }^{38}$, aby skutecznie pouczyć swoich katechumenów: „Grecy czczą tych, którzy zginęli trafieni piorunem. Piorun jednak nie spada $z$ nieba bez wcześniejszego wyroku. Jeśli zatem ktoś nie wstydzi się czcić znienawidzonych przez Boga rażonych piorunem, to ty wstydzisz się oddawać cześć umiłowanemu przez Boga Jego Synowi, który umarł dla ciebie na krzyżu?”. Chrześcijanie długo pozostawali pod wpływem tego wyobrażenia; świadczy o tym pewne zdarzenie, które miało miejsce w Bitynii na początku V wieku ${ }^{39}$. Do św. Hypatiosa przyniesiono człowieka imieniem Agatangelos, którego członki były dotknięte tak straszliwymi konwulsjami, że patrzącym na niego włos się jeżył i wznosili ręce do Boga; panowało bowiem przekonanie, że skoro trafił w niego piorun, to w ten sposób „wstąpił w niego demon”.

Sam bóg więc zstępował na ziemię w błyskawicy i zamieszkiwał w osobie rażonej piorunem. Stąd wypływała rytualna konsekwencja, aby nie spopielać zmarłych trafionych piorunem, ale grzebać ich w ziemi dokładnie w tym miejscu, w którym zginęli. Nie był to jedynie rzymski, ale i grecki oby$\mathrm{czaj}^{40}$. Odchodząc od tego zwyczaju, Eurypides [w jednej ze swoich tragedii]

38 Cyryl Jerozolimski w XIII Katechezie c. 37 [por. wydanie: Cyrille de

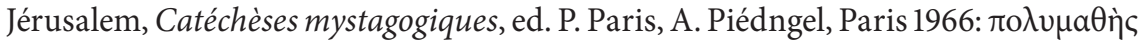

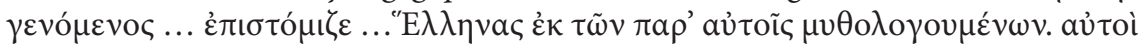

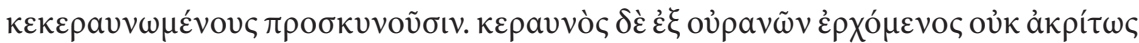

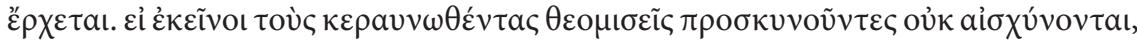

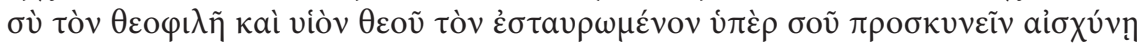
(por. pol. wydanie: Cyryl Jerozolimski, Katechezy przedchrzcielne i mistagogiczne, tłum. W. Kania, wstęp J. Bojarski, oprac. M. Bogucki, Kraków 2000, s. 204: „Piorun spada z nieba, ale nie spada przecież niepostrzeżenie. Jeśli poganie nie wstydzą się czcić niemiłych bogu zabitych piorunem, ty masz się wstydzić czcić Ukrzyżowanego Bożego Syna, którego Bóg kocha?” (przyp. red.)].

39 Kallinikos w Żywocie św. Hypatiosa, s. 37 [por. wydanie: Callinici, De vita s. Hypatii liber, hrsg. von Seminarii Philologorum Bonnensis Sodales, Leipzig 1895:

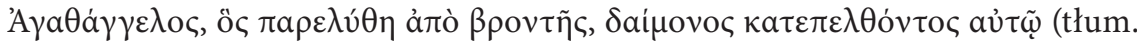
pol.: „w Agatangelosa wszedł demon, gdyż został rażony piorunem”) (przyp. red.)].

${ }^{40}$ G. Wissowa, Religion und Kultus der Römer, München 1902, s. 472, 4;

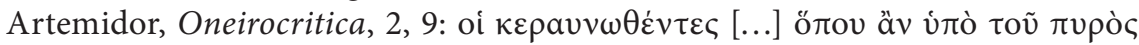


pozwolił sobie na spopielenie zwłok trafionego piorunem Kapaneusa; miano je jednak spalić nie na wspólnym stosie, na którym zamierzano spopielić pozostałych poległych pod Tebami bohaterów, lecz oddzielnie. Eurypides wymownie nazwał ten oddzielny stos „skarbcem Zeusa”41: uśmiercony piorunem musiał bowiem być ulubieńcem Zeusa. Zrozumiałe jest, że gdy piorun trafiał w grób, jak miało to miejsce w przypadku spartańskiego wodza Likurga i poety Eurypidesa, uznawano to za szczególne wyróżnienie i dowód przychylności bogów wobec zmarłego ${ }^{42}$.

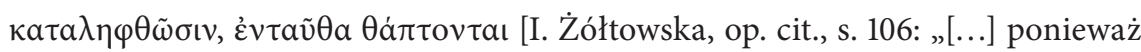
nieszczęśników rażonych piorunem zostawia się tam, gdzie padli; jeśli nie przeżyli wypadku, zostają pogrzebani w miejscu, gdzie skonali” (przyp. red.)]; por. J. Grimm, Kleinere Schriften, t. 2, Berlin 1865, s. 228.

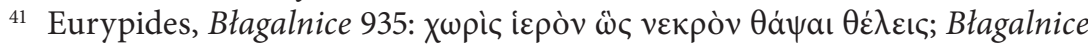

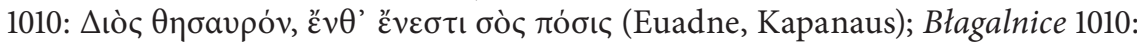

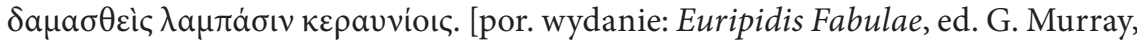
t. 2, Oxford 1913 (tłum. pol.: „Chcesz pogrzebać zmarłego tak poza miejscem świętym?... [widzisz] Zeusa skarbiec, tam znajduje się twój mąż, powalony przez światła piorunowe"); por. tłumaczenie według Eurypides, Tragedie, t. 1, tłum. J. Łanowski, Warszawa 2005, s. 432 i 436: Błagalnice 935: „A więc przeklęty. Grzebiesz go osobno?”; Błagalnice 1010: „A więc już widzisz go, stanęła blisko ten stos, Dzeusowy skarbiec, gdzie spoczywa twój mąż, piorunu żagwią powalony" (przyp. red.)]. Trudno uwierzyć, ale to śmiałe, lecz trafne wyrażenie Wecklein oraz

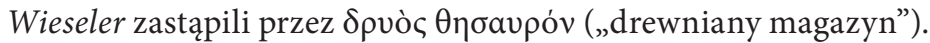

${ }^{42}$ Plutarch, Lykurgos 31, 5-6 [por. wydanie: Plutarchi vitae parallelae, Bd. 3, Fasc. 2, hrsg. von K. Ziegler, H. Gärtner, Stuttgart-Leipzig 1973 (zob. tłum. pol.: Plutarch, Żywoty równoległe, t. 1, tłum. K. Korus, Warszawa 2005, s. 251: „Tradycja głosi, że kiedy przywieziono jego szczątki do ojczyzny, w grób uderzył piorun, a to później nie przytrafiło się zgoła żadnej innej słynnej postaci z wyjątkiem Eurypidesa, który zmarł i został pochowany w Macedonii, w pobliżu Aretuzy. Stało się to zresztą ważnym argumentem dla miłośników Eurypidesa, że mianowicie po śmierci tylko jemu jednemu zdarzyło się to, co wcześniej spotkało człowieka ukochanego przez bogów i przesiąkniętego pobożnością") (przyp. red.)]. W Żywocie Eurypidesa (Scholia in Euripidem, hrsg. von E. Schwartz, Bd. 1, Berlin 1887, s. 3, wers 11) jest w tym kontekście mowa nie tylko o grobie pod Aretuzą w Macedonii,

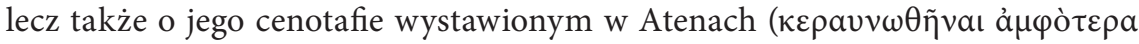
$\mu \nu \eta \mu \varepsilon \tilde{\alpha} \alpha)$ („oba groby zostały rażone piorunem”). 
Ważną i bardziej starożytną paralelę do [specjalnego] obchodzenia się z rzeczami i ludźmi trafionymi piorunem stanowi pewien egipski zwyczaj, o którym wspomina Herodot $(2,90)$ : gdy znajdywano na brzegu zwłoki osób, które utonęły w Nilu lub zostały zabite przez krokodyla, to takich ludzi uważano za istoty wyższe. Do ich zwłok nie posiadała praw rodzina, lecz musieli je pochować własnymi rękami kapłani Nilu, a okoliczni mieszkańcy byli zobowiązani do zatroszczenia się o ich mumifikację oraz o to, by je $\dot{\omega} \varsigma$

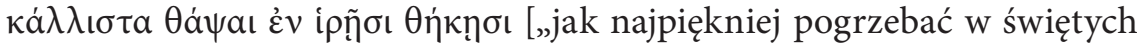
trumnach"; Herodot, 2.9043]. Przejście tej procedury było warunkiem ubóstwienia jeszcze Antinousa.

\section{3.}

Jak już powiedzieliśmy, mieszkańcy Tarentu oddawali cześć bogu imieniem

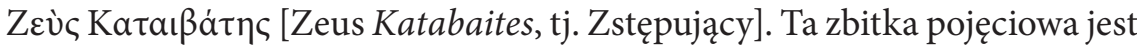
językowo wprawdzie wygodniejsza i łatwiejsza do zastosowania niż mantinejskie określenie Zev̀ৎ Kepavvó ‘ [Zeus Piorun], ale co do swej istoty na tyle do niego podobna, że możemy ją potraktować jako kolejną przesłankę

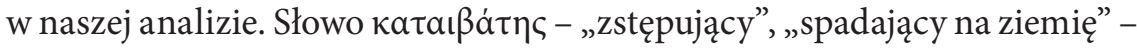
pierwotnie było przymiotnikowym określeniem funkcji w formie przydomka nadawanego piorunowi; zobacz u Ajschylosa (Prometeusz skowany 358):

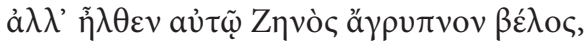

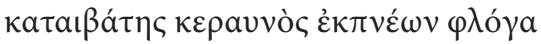

[lecz przybył do niego (tj. do Tyfona) czuwający pocisk Zeusa, piorun zstępujący, ziejący ogniem $\left.{ }^{44}\right]$.

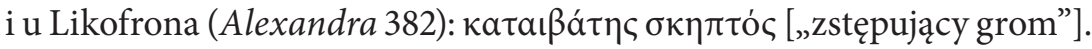

${ }^{43}$ Por. pol. tłum.: Herodot, Dzieje, tłum. S. Hammer, Warszawa 2015, s. 131: „Jeżeli znajdą kogoś, czy to z Egipcjan, czy tak samo z cudoziemców, kto zginął porwany przez krokodyla albo pochłonięty przez samą rzekę, muszą go bezwzględnie mieszkańcy tego miasta, przy którym został wyrzucony na ląd, zabalsamować, jak najpiękniej przystroić i pochować w świętych grobach. Nie śmie go też nik inny ani z krewnych, ani z przyjaciół dotknąć, tylko sami kapłani Nilu własnoręcznie go grzebią, jak gdyby był czymś więcej niż trupem człowieczym” (przyp. red.).

44 Por. pol. tłum.: Prometeusz w okowach, [w:] Ajschylos, Tragedie, op. cit., s. 200: „Lecz oto Zeusa pocisk bezsenny, z niebieskiej / zlatujący wyżyny ognionośny piorun / runął nań [...]” (przyp. red.). 


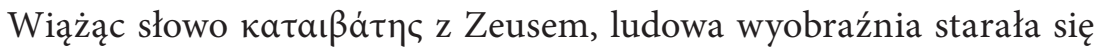
uchwycić to, co w piorunie jest istotne: zstępowanie boga i jego zamieszkanie na ziemi. Ponadto określając tak sam piorun, uczyniła to słowo imieniem boga, unikając zarazem toporności nazwy pospolitej. Było to bowiem bardzo rozpowszechnione określenie bóstwa zstępującego na ziemię w postaci błyskawicy. W Atenach na Akropolu znajdowało się niedostępne miejsce poświęcone Zeusowi Zstępującemu; fragment kolumny należącej do tej prze-

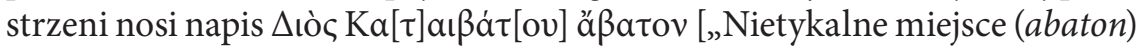
Zeusa Zstępującego"] (CIA IV 2, nr 1659', s. 265); inny ateński blok ka-

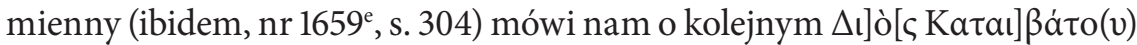

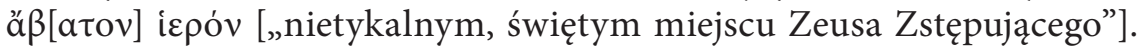
Natomiast Arystofanes w komedii Pokój (42) powiada:

ov̉к है $\sigma \theta^{\prime}$ ö $\pi \omega \varsigma$

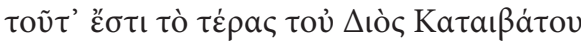

[Nie inaczej,

toż to cudo Zeusa Zstępującego ${ }^{45}$,

a Likofron (Alexandra 1370):

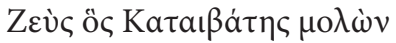

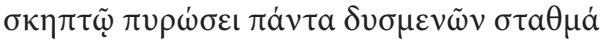

[Zeus, przychodząc jako Zstępujący,

gromem spopieli wszystkie wrogie gospodarstwa].

To samo określenie nadano wydzielonej przestrzeni ( $\varphi \rho \alpha ́ \gamma \mu \alpha)$, która wraz z przynależącym do niej ołtarzem znajdowała się w Olimpii obok wielkiego ołtarza wzniesionego z popiołów (Pauzaniasz V, 14, 10). Spotykamy je także

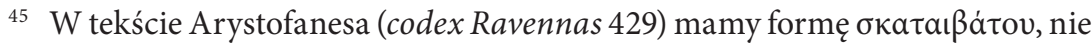

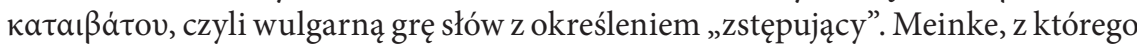
wydania korzystał Usener, poprawił to miejsce ze względów obyczajowych; por. wydanie: Aristophanis Fabulae, ed. N.G. Wilson, vol. 1, Oxford 2007, s. 284 (przyjęta

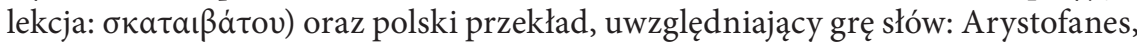
Komedie, t. 1, tłum. J. Ławińska-Tyszkowska, Warszawa 2001, s. 341: „Nie inaczej jak Zeus to cudo zesłał Gównowładny" (przyp. red.). 
na wyspach Paros i Melos ${ }^{46}$. Wydaje się, że ludowa etymologia przekształcała

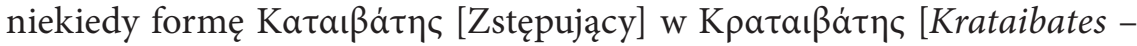
„kroczący z mocą”]. Marmurowa kolumna z Nauplion z surowo obrobionym wizerunkiem Zeusa zwróconego w prawą stronę i biorącego rozmach w ge-

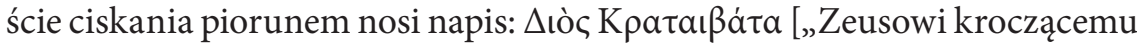
z mocą"] (IG Pelop. I 669). O ile kamieniarz nie popełnił tu błędu, to pierwsza część słowa została przekształcona pod wpływem wyobrażenia, zgodnie z którym piorun stanowi кpátos $\Delta$ iò [kratos Dios - „moc Zeusa”], por. na

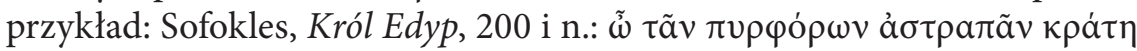
$v \varepsilon \dot{\varepsilon} \omega v, \tilde{\omega}$ Z $\varepsilon \tilde{v}$ [„O Zeusie, niosący ogień, błyskawicę, posiadający moc”],

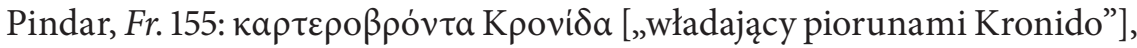
Horacy, Carmina III 3, 6: fulminantis magna manus Iovis [„wielka ręka Jowisza miotającego gromy”]. Wspomnijmy tu staranność, z jaką w micie

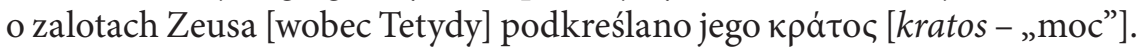

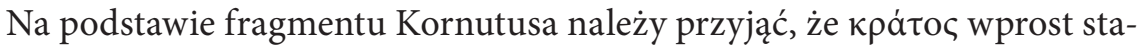

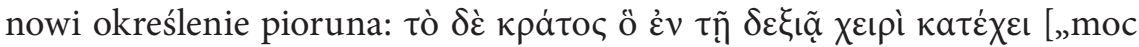

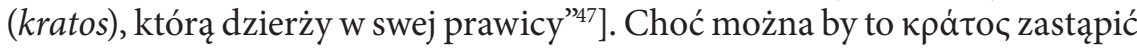
$\mathrm{w}$ tym miejscu przez $\beta \dot{\varepsilon} \lambda$ oc [belos - pocisk], byłaby to zmiana zbyt banalna i nieprawdopodobna.

Zachowało się jeszcze trzecie, podobne określenie dialektalne. W pobliżu Gytion Pauzaniasz (III 22, 1) widział święty kamień nazywany Zev̀

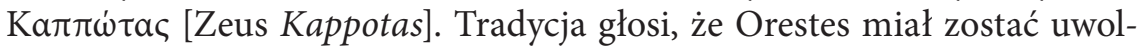
niony od szału właśnie dzięki temu, że na nim spoczął, stąd skała otrzymała

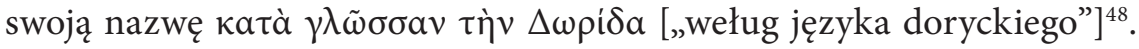

46 Paros: O. Rubensohn, Paros II. Topographie, Mitteilungen des deutschen Archäologischen Instituts: athenische Abteilung 26 (1901), s. 176, przypis 1: $\Delta \mathrm{l}$ [òc]

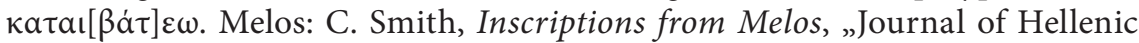

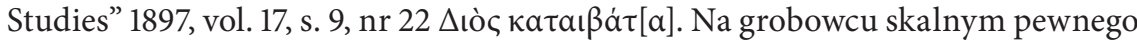
eunucha: R. Heberdey, A. Wilhelm, Reisen im Kilikien, Wien 1896, s. 38, nr 94 znaj-

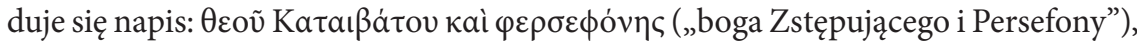
tutaj może chodzić jedynie o Hadesa; por. przyp. 29.

47 Cornuti Theologiae graecae compendium, hrsg. von K. Lang, Leipzig 1881, s. 10, w. 10-13.

48 Por. pol. tłum.: W świątyni i w micie. Z Pauzaniasza Wędrówek po Helladzie księgi I, II, III i VII, tłum., wstęp i komentarz J. Niemirska-Pliszczyńska, Wrocław 


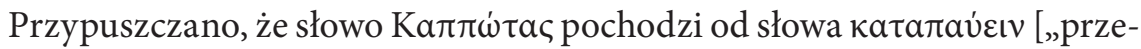
rwać”, „odpocząć”]. Jest to jednak równie niewiarygodne jak to, że taki kamień Orestes mógł podnieść do rangi fetyszu Zeusa. Cząstka $\pi \omega \tau-$ na-

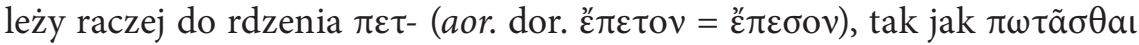
do $\pi \dot{\varepsilon} \tau \varepsilon \sigma \tau \alpha$ l (por. $\sigma \tau \rho \dot{\varepsilon} \varphi \varepsilon \iota v \sigma \tau \rho o \varphi \eta ́ ~ \sigma \tau \rho \omega \varphi \tilde{\alpha} \sigma \theta \alpha \mathrm{l}$ ). Tak jest i w przypadku Ka $\pi \omega \dot{\tau} \tau a \varsigma$, czyli „Spadającego”, który stanowi synonim określenia

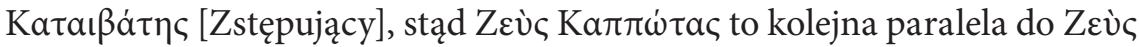
Kepavvóc. Kamień noszący taką nazwę mógł być więc meteorytem czczonym jako wcielony piorun. Warto zauważyć, że w pobliżu Gytion znaleziono

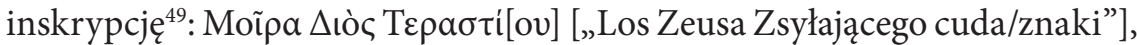
która pozwala nam poznać wcześniejszą postać tego pojęcia. Bowiem $\tau \dot{\varepsilon} \rho \alpha \varsigma$, (łac.) ostentum [„,cud/znak”], to w pierwotnym znaczeniu błyskawica ${ }^{50}$, co mam nadzieję wykazać w innym miejscu.

\section{4.}

Po przedstawieniu znanych mi faktów i wyjaśnieniu treści omawianych pojęć jesteśmy w stanie precyzyjniej ująć proces kształtowania się pewnych wyobrażeń. Keraunos, pierwotnie ogólnogrecki i w niektórych rejonach czczony jeszcze w bardzo późnych czasach, był błyskawicą lub piorunem nie w ogólnym znaczeniu nazwy pospolitej, ale zawsze według specyfiki określonego przypadku; był bóstwem, które przychodziło na ziemię w postaci konkretniej błyskawicy, aby na niej zamieszkać. Jest to jasny przykład tego, co nazwałem „bóstwem chwilowym”51 (Augenblicksgott), tj. pewnego wyobrażenia religijnego biorącego swój początek z konkretnego zjawiska i niewykraczającego poza nie. Ściśle rzecz ujmując, Keraunos powinien wykluczyć inne [pioruny], ponieważ boska moc może zostać wyemitowana i związana z ziemską siedzibą [tj. miejscem uderzenia pioruna] tylko w pojedynczej manifestacji zjawiska. Naiwny sposób myślenia nie

1973, s. 341: „Najwyżej trzy stadia od Gytionu leży nieobrobiony kamień. Podobno Orestes, usiadłszy na nim, doznał uwolnienia od szału. $Z$ tej przyczyny ów kamień otrzymał nazwę Zeusa z przydomkiem Kappotas, w języku Dorów” (przyp. red.).

49 A. Skias, Topographika Gytheiou, „Ephēmeris archaiologikē” 1892, s. 57.

50 Por. na przykład Arystofanes, Pokój 42 (zob. wyżej, s. 639).

${ }^{51}$ H. Usener, Götternamen, op. cit., s. 279 i n. 
wyczuwał zrazu tej sprzeczności. Stopniowo jednak musiał się pogodzić z przekonaniem, że takie bóstwo można pojmować jedynie jako wielość, musiało więc w końcu dojść do oddawania czci Kepavvoí [„piorunom”],

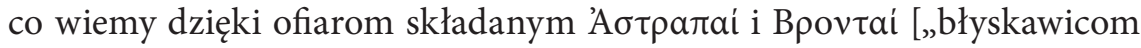
i gromom"] ${ }^{52}$. Dopiero taka wielość mogła się w dalszej kolejności skonsolidować w jednolite wyobrażenie w taki sposób, że objęło ono różne pod względem rodzaju i przyczyny przypadki, tak jak to widzimy na przykładzie bóstw z rzymskich Indigamenta ${ }^{53}$. Powstawało wówczas „bóstwo specjalne” (Sondergott), jeśli mogę posłużyć się takim skrótem, który wybrałem, idąc za propozycją Edvarda Lehmanna, który w ten sposób chciał określić ważną i rozległą klasę bóstw sytuujących się pomiędzy „bóstwami chwilowymi” (Augenblicksgötter) a bóstwami osobowymi (persönliche Gottheiten). Są to bóstwa klarowne pod względem wyobrażenia i ograniczone, ale wyraźnie rozgraniczone między sobą w ogólnym zakresie poprzez imiona, a więc wybrane ze względu na typ lub gatunek pojęcia, które owe bóstwa obrazowały. W przypadku zjawiska chwilowego (Augenblicke) ten etap został osiągnięty wówczas, gdy wizerunek pioruna zaczął być przedmiotem kultu. Przestał być wtedy związany z jednorazową błyskawicą i stał się pojęciem gatunkowym. Nie tylko w przypadku macedońskiego Keraunosa, ale też w przypadkach starogreckich, od których rozpoczęliśmy nasze rozważania, musimy rozpoznać już „bóstwo specjalne” (Sondergott). Możemy w ten sposób cofnąć się aż do labrysu z czasów staroachajskich. Ten sam etap reprezentuje Kepaúvıo

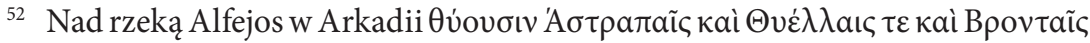
(„składają ofiary błyskawicom, burzom, i gromom”), Pauzaniusz VIII 29, 1 [por.: Pausaniae Graeciae descriptio, hrsg. von M.H. da Rocha-Pereira, Bd. 1-3, Leipzig 1973-1981 (przyp. red.)]; por. Sofokles, Elektra 823 [por. Sophoclis Fabulae, ed. A.C. Pearson, Oxford 1928, oraz tłum. pol.: Sofokles, Antygona; Król Edyp, tłum. K. Morawski, Wrocław 2004: кعрavvoì $\Delta$ ió („pioruny Zeusa”) (przyp. red.)].

53 Indigamenta - listy imion i/lub epitetów italskich i latyńskich bogów (di indigetes) przywoływanych $\mathrm{w}$ modlitwach i inkanatacjach wraz $\mathrm{z}$ ich prerogatywami. Według tradycji zostały ułożone przez Numę Pompiliusza, przechowywane zaś były przez collegia pontyfików. Obecnie znane są jedynie z antycznych przywołań (Warron, Ojcowie Kościoła), które zostały zebrane w leksykonie Roschera: W.H. Roscher, Ausführliches Lexikon der griechischen und römischen Mythologie, Leipzig 1890-1894, Bd. II, cz. 1, s. 187-233 (przyp. red.). 
[Piorunowy], wraz ze swoim żeńskim odpowiednikiem Kepavvía, o których wspomina się $\mathrm{w}$ formule przekleństwa $\mathrm{z}$ napisu nagrobnego $\mathrm{z}$ Kition [Larnaka] na Cyprze ${ }^{54}$. Dalekim echem tego rodzaju wyobrażeń jest jeszcze „anioł błyskawicy”, który według środkowoniemieckich wierzeń ${ }^{55}$ podczas burzy nawiedza domostwo albo nad nim przelatuje.

Kolejny i ostatni etap ewolucji takiego wyobrażenia polega na przekształceniu spersonifikowanej abstrakcji w osobową, plastyczną postać bóstwa. Takie przekształcenie zachodzi łatwiej i w sposób pełniejszy o tyle, o ile nazwa bóstwa na skutek przekształcenia brzmienia albo przez obumarcie rdzenia słowa staje się już dłużej nieczytelna, a więc zamienia się w imię własne. Gdy natomiast nazwa bóstwa opiera się takiemu wyposażeniu jej w osobową egzystencję, a stałe apelatywne użycie słowa staje się ku temu poważną przeszkodą, to takie wyniesienie do statusu osobowej egzystencji dokonuje się przez to, że stare „bóstwo specjalne” podporządkowuje się bóstwu osobowemu, stając się szczególną formą objawienia się wyższego bóstwa: imię „bóstwa specjalnego” zostaje w formie niezmienionej lub uprzymiotnikowionej przypisane bóstwu osobowemu jako jego atrybut. Proces ten dokonuje się tym pełniej, im bardziej znaczące i ważniejsze jest zjawisko, któremu patronuje „bóstwo specjalne”. Na gruncie germańskim pewną formę istnienia osobowego uzyskał Donar-Thór(r) [bóg Thor > staronordyckie Pórr - „grom”]. Grecy porzucili Keraunosa i przenieśli jego wyobrażenie na złożoną osobowość [ontyczną] Zeusa. Już w eposie homeryckim dawnemu indogermańskiemu bóstwu jasności dnia została przypisana wszechmoc, a jego siła wyrażała się głównie we wstrząsających zjawiskach burzowych: był on „gromadzącym chmury”, „ciskającym gromy” i „grzmią-

54 Le Bas-Waddington VI, nr 2739, s. 635 według Ph. Le Bas, W.H. Waddington, Explication des inscriptions grecques et latines recueillies en Grèce et en Asie Mineure, Paris 1847-1870; iidem, Voyage archéologique en Grèce et en Asie Mineure (...) pendant 1834 et 1844, Paris 1847-1877, vol. III, cz. 5: Inscriptions grecques et latines recueillies en Grèce et en Asie Mineure (1870-1876); cz. 6, ed. W.H. Waddington:

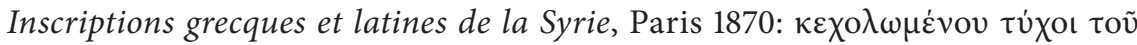

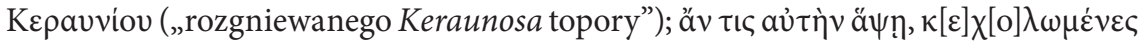

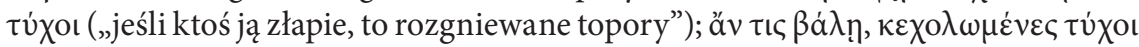
$\tau \tilde{\eta} \varsigma$ Kepavviac („,jeśli ktoś rzuci, to rozgniewane topory Keraunosa”).

55 J. Kehrein, Volkssprache und Volkssitte in Nassau, t. 2, Bonn 1872, s. 245. 
cym”. Homer i pozostali poeci dysponowali niewyczerpanym zasobem wyrażeń wyobrażających ten aspekt potęgi Zeusa ${ }^{56}$, do sfery kultu natomiast określenie Zzùc Kepaúvıo [Zeus Piorunowy] weszło dosyć powszechnie $\mathrm{w}$ epoce hellenistycznej ${ }^{57}$. Stopienie się z Zeusem oznaczało całkowite prze-

56 Przegląd podaje L. Preller-C. Robert, Griechische Mythologie, Bd. I, Berlin 1872, s. 118, przyp. 1.

57 Olimpia: ołtarz Zeusa w Altis według: Pauzaniasz V, 14; Tazos: $\Delta$ iò $\varsigma$ Kepavviou („Zeusa Piorunowego”), następnie piorun z podwójnym trójzębem według: E.L Hicks, J.Th. Bent, Inscriptions from Thasos, „Journal of Hellenic

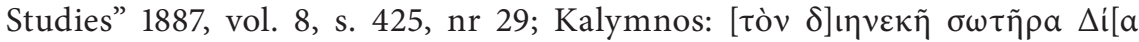

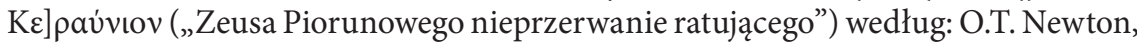
Ancient Greek Inscriptions in the British Museum. Oxford 1883, cz. 2, nr 321, 9; Pergamon: $\Delta$ ì Kepavvi $\omega$ („Zeusowi Piorunowemu”) według: Die Inschriften von Pergamon, hg. von M. Fränkel, Berlin 1890, nr 232; mniejsze ołtarze z tym samym napisem: ibidem, 329; Frygia: wyrocznia z kości do gry z Ormelii [ $\Delta$ iòs? K] cpavvíov („Zeusa Piorunowego”) według: G. Cousin, Inscription d’Ormellé de Phrygie, „Bulletin de correspondance hellénique” 1884, vol. 8, s. 503; Lidia: $\Delta$ ì

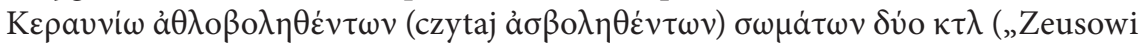
Piorunowemu dwa poczernione sadzą ciała" itd.) według: CIG 3446, Ph. Le Bas, W.H. Waddington, Voyage archéologique en Grèce et en Asie Mineure..., op. cit., vol. 3, cz. 5: Inscriptions grecques et latines recueillies en Grèce et en Asie Mineure..., op. cit.; cz. 6, ed. W.H. Waddington, Inscriptions grecques et latines de la Syrie,

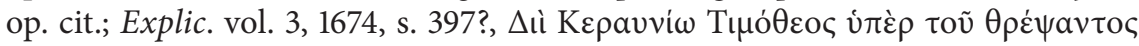

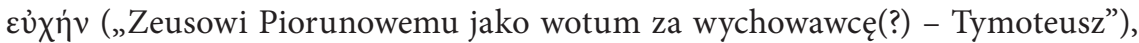

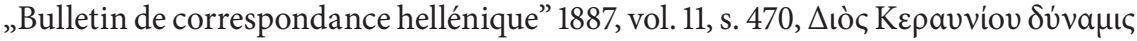
(„moc Zeusa Piorunowego”) (Tiatyra), „Bulletin de correspondance hellénique” 1886 , vol. 10, s. 401, H. Lechat, G.A. Radet, Inscriptions de Lydie, „Bulletin de correspondance hellénique" 1887, vol. 11, s. 445-484; Kiton na Cyprze: CIG 2641; Syria:

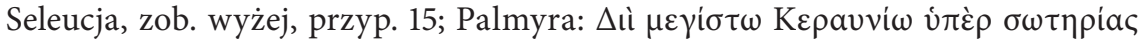
(„Zeusowi Największemu Piorunowemu za ocalenie”) CIG 4501, region Damaszku: ípev̀c $\Delta$ iòs Kepavvíov („kapłan Zeusa Piorunowego”) CIG 4520; Sycylia: ołowiany pocisk do procy z Nín $\Delta$ iò K Kepavvíov („Zwycięstwo Zeusa Piorunowego”); ołtarz z Góry Albańskiej: $\Delta$ ı̀ Kepavvíw („Zeusowi Piorunowemu”) IGSI 1118. Z literatury należy przywołać: Arystoteles, De mundo 7, 401 a 17 [wyd. pol.: O świecie, tłum., wstęp i komentarz A. Paciorek, Warszawa 1990 (przyp. red.)], Anthologia Palatina 7, 49 [epigram autorstwa Bianora z Bitynii; por. wydanie: The Greek Anthology, ed. and transl. W.R. Paton, vol. 1-5, $2^{\text {nd }}$ edition, London - Cambridge, 
wartościowanie omawianego wyobrażenia. Samodzielny niegdyś Keraunos pozostał jedynie bronią w ręku Zeusa, jedynie pewnym symbolem. Zwał się odtąd $\Delta$ iòc Kepavvóc [„Piorunem Zeusa”] (m.in. Homer, Iliada, XIV,

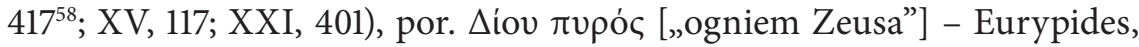

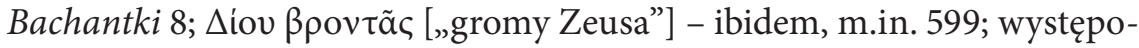
wał jako jego „pocisk” ( $\beta \dot{\varepsilon} \lambda$ oৎ) jak u Ajschylosa, Prometeusz skowany 358:

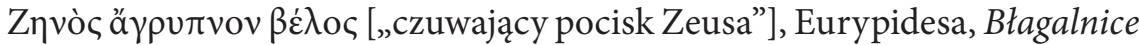

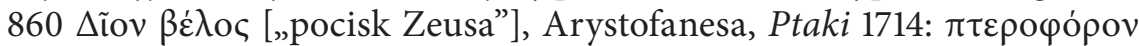

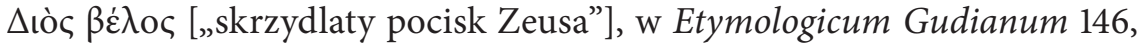

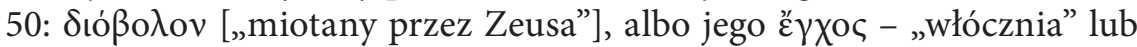

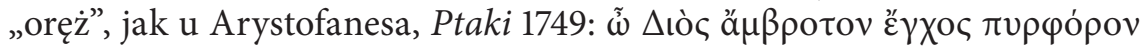
[„O nieśmiertelna, ogień niosąca włócznio Zeusa”], Bakchylidesa 8, 10:

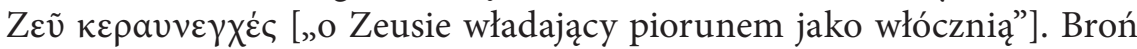
ta została wykuta przez cyklopów ${ }^{59}$ w podziemnej kuźni, nie mogła więc nigdy zostać przez bóstwo złamana. Poezja i sztuki plastyczne prześcigały się w wyobrażaniu miotającego gromem bóstwa uranicznego. W podobny sposób labrys, który w czasach achajskich [tj. mykeńskich], a potem jeszcze przez długi czas na wyspie Tenedos [Bozca] był obiektem bezpośredniej czci jako fetysz, stał się bronią w ręku Zeusa Labrayndeusa.

MA 1948-1953: Zavì Kepavveí („Zeusowi Piorunowemu”) (przyp. red.)]. Por. M. Fräkel, Die Inschriften von Pergamon, Berlin 1890/1895, s. 134. Warto zauważyć, że pierwsza i ostatnia inskrypcja z Lidii, z Tazos i z Pergamonu, a także z Góry Albańskiej wyraźnie zostały dedykowane w miejscach uderzenia pioruna; legenda z błyskawicą łączy także ołtarz z Olimpii. Na jednej z inskrypcji z Tegei (według: Ph. Le Bas, W.H. Waddington, Voyage archéologique en Grèce et en Asie

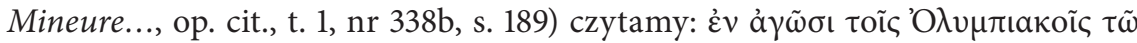

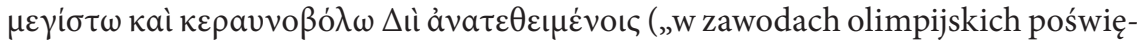
conych Największemu i Rzucającemu Pioruny Zeusowi”); ta późna inskrypcja nie pozwala jednak na wyciągnięcie żadnych wniosków dotyczących terminologii kultowej.

58 Zamiast $\Sigma$ (pieśń XVIII) - jak jest w oryginalnym tekście Usenera - powinno być $\Xi$ (pieśń XIV) 417 (według: Homeri Ilias, t. 2, hrsg. von M.L. West, München -

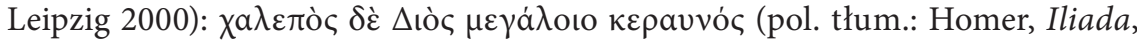
tłum. K. Jeżewska, Warszawa 2005, s. 257: „ciężkie i przykre Dzeusa wielkiego są gromy") (przyp. red.).

59 Hezjod, Theogonia 141. 504; Wergiliusz, Georgiki 4, 170; Eneida 8, 426 i n. 
W ten właśnie prosty i zrozumiały ciąg rozwojowy wepchnęła się dziwna konceptualizacja Zeusa Keraunosa z Mantinei, do której dołączyły, jako odpowiedniki, Zeus Kappotas [Spadający] z Gytion i Zeus Kataibates [Zstępujący]. Taki proces zawiera w sobie wewnętrzną sprzeczność: z jednej strony dotyczy konkretnej błyskawicy, która zamieszkuje w miejscu przez siebie trafionym, a z drugiej opisuje tę błyskawicę jako najwyższy, w pełni osobowy byt. Uwzględnienie tej ewolucji chroni nas przed pomyłką interpretacyjną. Można by zatem przypuszczać, że w zbitce „Zeus Keraunos” pierwsza część nadal zachowała swoje pierwotne znaczenie, które jeszcze nie zniknęło całkiem z greckiego zasobu językowego ${ }^{60}$, czyli znaczenie bóstwa światła dziennego, i to do niej dołączony został na zasadzie luźnego połączenia „Keraunos”, podobnie jak w przypadku sanskryckiego Indrägni ${ }^{61}$. Takie wyjaśnienie jest jednak błędne, gdyż wyobrażenie Zeusa jako boga burzy zostało ukształtowane jeszcze przed eposem homeryckim. Nie możemy przejść do porządku dziennego nad podporządkowaniem koncepcji partykularnej wobec osobowej i musimy tę zbitkę sprowadzić do paradygmatu opisywanego jako paradygmat słowotwórczy ảvì $\rho$

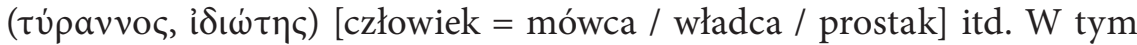
przypadku mamy więc: „Zeus w swojej funkcji jako piorun”. Dawnego Keraunosa wyparł na gruncie greckim Zeus Kataibates, dla którego w VI i V wieku [p.n.e.] fundowano [jako kultowe] miejsca uderzenia piorunów, a w czasach hellenistycznych również Zeus Keraunios, do którego jeszcze zawężono to wyobrażenie, czego dowodzi ilość świadectw przytoczonych w przypisie nr 45. Przypadek ten potwierdza wyraźnie naszą obserwację, że dane wyobrażenie może o stulecia wyprzedzać kult i określoną przezeń koncepcję. Zadziwia fakt, że obok obecnego już w eposie [homeryckim], dobrze ugruntowanego i ogólnogreckiego wyobrażenia Zeusa ciskającego gromami, aż do IV wieku [p.n.e.], a nawet dłużej, mogło się utrzymywać dawne przekonanie o bóstwie zstępującym na ziemię każdorazowo w pojedynczej błyskawicy. Rozwikłanie tej zagadki nie jest jednak trudne. Dawne przekonanie utrzymywało się niewzruszenie dzięki pochodzącemu jeszcze

60 Zob. H. Usener, Götternamen, op. cit., s. 68 i n.

${ }^{61}$ Indra agni - połączenie imion Indry i Agniego. Indra był bóstem uraniczno-atmosferycznym, odpowiadającym m.in. za burze i opady. Jego głównym atrybutem i bronią był piorun (wadżra); Agni zaś to bóg ognia (przyp. red.). 
z pradziejów zwyczajowi odgradzania od świata profanum miejsc trafionych piorunem jako świętej siedziby bóstwa. Nie dało się wykorzenić tego zwyczaju, toteż wszechwładny Zeus, niekwestionowany Pan piorunów, musiał jako Zeus Kataibates, ewentualnie Zeus Keraunos albo Zeus Kappotas, dać się zamknąć w ciasnocie miejsca rażonego piorunem. Bowiem wbrew Epikurowi i jego szkole nadal utrzymywało się przekonanie, że to w błyskawicy bóstwo zstępuje na ziemię ${ }^{62}$.

\section{5.}

Chociaż to dziwne połączenie słów [Zeus i piorun] wydaje się przeczyć ewolucji omawianego pojęcia, to jednak okazuje się ono nieuniknionym kompromisem pomiędzy kultem a wyobrażeniem, a tym samym potwierdzać jej poprawność. Nie mogę tu nie wskazać na pełną analogię, jakiej dostarcza kult rzymski zarówno dla takiego związku pojęciowego, jak i dla całego procesu ewolucji. Najstarszą formą jest tu „goły” kult fulgura [„pioruna”, poświadczony przez kamień z Brixellum [współ. Brescello] (CIL XI 1024): sacrum publicum Fulguris [„miejsce święte pioruna”]. Tak jak u Greków w okresie klasycznym Zeus Kataibates, tak tutaj panował Iuppiter Fulgur [Jowisz Piorun] ${ }^{63}$ : kalendarze pod datą 7 października wymieniają ofiarę składaną Iovi Fulguri [Jowiszowi Piorunowi], a Witruwiusz (I, 2, 5) poświadcza, że było to wyrażenie powszechnie używane. To samo stadium reprezentuje Iuppiter lapis [Jowisz kamień], którego wkrótce poznamy, a także Zeus Kappotas. Rozszerzenie tej formy pojawia się w formule dedykacyjnej: Iovi Fulguri Fulmini [Jowiszowi Piorunowi Gromowi] CIL XII 1807. Dopiero później, jak przyznaje Georg Wissowa, nazwy pospolite zostały zastąpione $\mathrm{w}$ inskrypcjach i na monetach wyrażeniami przymiotnikowymi, do których należą również nomina agentis [nazwy odczasownikowe]: Iuppiter Fulgerator (i Fulgurator), Fulminaris i Fulminator, Fulminator Fulgerator

${ }^{62}$ Sekstus Empiryk, Adversus mathematicos, 7, 19 [por. wydanie: Sexti Empirici

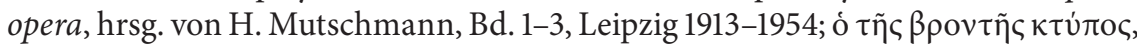

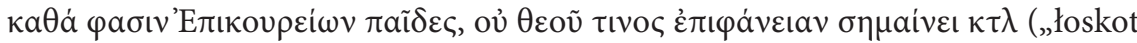
gromu, jak mówią adepci epikureizmu, nie oznacza epifanii jakiegoś boga” itd.) (przyp. red.)].

63 L. Preller, H. Jordan, Römische mythologie, Bd. 1, Berlin 1881, s. 190 i n; G. Wissowa, Religion und Kultus der Römer, München 1902, s. 107. 
[Jowisz ciskający błyskawice; ciskający pioruny]. Charakterystyczne dla Rzymu jest to, że obok dziennej błyskawicy Jupitera (fulgur dium) w oddzielne wyobrażenie kultowe rozwinęła się błyskawica nocna. Summanus był z pewnością odbierany jako odrębne bóstwo ${ }^{64}$ i musiał, gdy łączono go $z$ bogiem osobowym, być rozumiany raczej jako forma objawienia się bóstwa chtonicznego. Przejwiało się to w kulcie poprzez czarny kolor zwierzęcia ofiarnego ${ }^{65}$ i w fakcie - niezrozumiałym już dla autorów naszych źródeł - że w inskrypcjach Iuppiter i Summanus byli ze sobą łączeni. Dlatego rozważna interpretacja musi uwzględniać taką możliwość, że oba przeciwieństwa występowały obok siebie, ponieważ się wzajemnie uzupełniały, a nie dlatego, że jedno musiało być podporządkowane drugiemu.

\section{6.}

Nasze rozważania byłyby niekompletne, gdybyśmy nie uwzględnili w nich także sposobu obrazowania (Verbildichung), któremu podlegało przedstawienie Keraunosa. Mogłoby się wydawać, że nie ma tu w ogóle miejsca na swobodny rozwój żadnego plastycznego wyobrażenia, gdyż miało ono już

${ }^{64}$ Owidiusz, Fasti VI, 731: quisquis is est, Summano („kimkolwiek on był, Summanowi [wzniesiono świątynie]"); Augustyn, Civitas Dei, IV, 23: nescio quem Summanum („[dawni Rzymianie czcili] nie wiem jakiego Summanusa”) [por. Owidiusz, Fasti / Kalendarz poetycki, tłum. E. Wesołowska, Wrocław 2008, s. 262: „Kiedy Pyrrusie byłeś postrachem dla Rzymian, w tym dniu niegdyś świątynię otrzymał Summanus, choć nie bardzo wiadomo, kim był ów Summanus"; Św. Augustyn, Państwo Boże, tłum. T. Kubicki, Kęty 2005 (Poznań 1930-1937), s. 169: „Czytamy w ich pismach, że starożytni Rzymianie czcili więcej nawet niż Jowisza jakiegoś tam Summana, boga nocnych piorunów, gdyż Jowisz ma władzę tylko nad dziennymi piorunami. Lecz gdy Jowiszowi wielką i wspaniałą wzniesiono świątynię, to dla samej świetności tej świątyni tak się licznie do Jowisza zbiegano, że z ledwością znajdzie się człowiek, który by przypomniał sobie, że przynajmniej gdzieś tam czytał imię Summana, bo żeby miał kto słyszeć, to i mowy nie ma" (przyp. red.)].

65 W. Henzen, Acta Fratrum Arvalium, Berlin 1874, s. 146. Jako imię Hadesa użyte zostało przez Arnobiusza, Adversus gentes, V, 37, por. Martianus Capella, hrsg. von F. Eyssenhardt, Leipzig 1886, ks. II, 161, s. 45: Plutonius... qui etiam Summanus dicitur („Pluton... który zwany jest również Summanusem”). Inskrypcje zob. L. Preller, H. Jordan, Römische mythologie, op. cit., 1, 244, przyp. 3. 
namacalny punkt zaczepienia, a tym samym granicę, w postaci meteorytu. $\mathrm{W}$ istocie, już w klasycznej starożytności powszechnym wyobrażeniem pioruna był właśnie spadający na ziemię meteoryt. Do dzisiaj odnajdywaną broń z epoki kamienia, czyli kamienne toporki, uważa się za „kamienie piorunowe" i dba o nie [jako o przedmioty magiczne]. Dobrze znany jest fakt, że w czasie bitwy nad Ajgospotamoj w 405 r. [p.n.e.] spadł na ziemię ogromny meteoryt, któremu mieszkańcy Chersonezu [Trackiego] oddawali później boską cześć ${ }^{66}$. „Kamień piorunowy” możemy rozpoznać również we wspominanym już kamieniu z Gytion w Lakonii, pod postacią którego

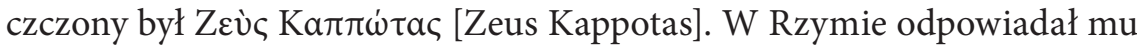
Iuppiter lapis [Jowisz kamień], krzemień (silex) przechowywany w świątyni Jowisza Feretriusa na Kapitolu, który przy zawieraniu traktatów i sojuszy służył jako najświętsze potwierdzenie uroczystych przysiąg ${ }^{67}$. Fecjał albo inna osoba składająca przysięgę w imieniu wspólnoty, aby ją złożyć, brał do ręki kamień i wypowiadając końcową formułę brzmiącą: Si sciens fallo, tum me Diespiter salva urbe arceque bonis eiciat uti ego hunc lapidem [„Jeśli świadomie kłamię, to niech Dispiter (tj. Jowisz) oszczędzi miasto i arks, a mnie odrzuci, tak jak ja odrzucam ten kamień"] ${ }^{68}$, rzucał go na ziemię.

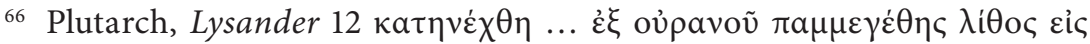

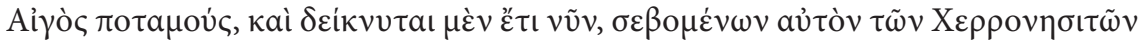
(„spadł... z nieba przeogromny kamień na Ajgospotamoj... a pokazują go jeszcze teraz, bo czczą go mieszkańcy Chersonezu [Trackiego]"). [Por. Plutarch, Cztery żywoty: Lizander, Sulla, Demostenes, Cyceron, tłum. M. Brożek, Warszawa 1954 (przyp. red.)].

67 Festus Pauli 92, 2 [na s. 114 w wydaniu Lindsaya, s.v. Manubiae (Iovis)]; Serwiusz, Komentarz do Eneidy VIII, 641 [por. wydanie: Servii Grammatici qui feruntur In Vergilii carmina commentarii, ed. G. Thilo, t. III, Leipzig 1881-1902 (repr. Hildesheim 1961 i 1986): antiquum Iovis signum lapidis siliceni („prastary Jowisza znak kamienia krzemiennego") (przyp. red.)].

${ }_{68}$ Festus Pauli 115, 4 (na s. 115 w wydaniu Lindsaya, s.v. Manalem lapidem) i nieco bardziej szczegółowo: Polibiusz, III, 25 [por. Polibiusz, Dzieje, tłum. S. Hammer, t. I, Wrocław 1957, na s. 129: „Przy pierwszym układzie przysięgali Kartagińczycy na bogów ojczystych, Rzymianie na Jowisza-Lapis według dawnego zwyczaju [...]. Przysięga na Jowisza-Lapis jest taka" - tu: treść przysięgi (przyp. red.)]. Por. Gelliusz, Noces Attices, I, 21.4. [Por. wydanie: A. Gelli noctes atticae, ed. P.K. Marshall, t. II, Oxford 1968 (repr. 1990): Iovem silicem, quod sanctissimum 
Aulus Gelliusz określił przysięgę na ten kamień jako najświętszą z przysiąg. Kamień jest gromem, którym bóstwo uraniczne ciska w krzywoprzysięzcę. Jupiter „uświęca błyskawicą” sojusze ${ }^{69}$. Kolejne zastosowanie silex [„krzemień"] znalazł przy składaniu ofiar, którymi pieczętowano oficjalne sojusze. Po odczytaniu uzgodnionych warunków (lex) upoważniony fecjał uderzał świnię ofiarną świętym krzemieniem (silex), wypowiadając przy tym następujące słowa: Iuppiter audi... si prior defexit publico consilio dolo malo, tum illo die, Iuppiter, populum Romanum sic ferito, ut ego hunc porcum hodie feriam, tantoque magis ferito quanto magis potes pollesque [„,Jowiszu, wysłuchaj... jeśli (lud rzymski) pierwszy podstępnie zerwie oficjalnie zawarte przymierze, to w tym dniu, Jowiszu, tak uderz w lud rzymski, jak ja dziś uderzam tego wieprza i niech będzie to uderzenie tak mocne, jak wielka jest twoja potęga i moc" $]^{70}$. Do dzisiaj rozpowszechniona jest u nas wiara, że kamienny toporek, tj. właśnie piorun, umieszczony pod dachem chroni dom przed błyskawicami ${ }^{71}$, a we Włoszech kamienne groty strzał z czasów

iusiurandum est habitum („na krzemień Jowisza, co uchodzi za najświętszą przysięgę") (przyp. red.)].

69 Wergiliusz, Eneida, XII, 200 [por. wydanie: P. Vergilius Maro. Aeneis, ed. G. B. Conte, Berlin - New York 2009: audiat haec genitor, qui foedera fulmine sancit (tłum. według: Wergliusz, Enedia, tłum. I. Wiśniewski, Kraków 1978, na s. 323: „Niech to usłyszy Jowisz [dokł. rodziciel], co pakty uświęca piorunem!” (przyp. red.)].

${ }^{70}$ Liwiusz, I 24, 7n. [por. wydanie: Titi Livi ab urbe condita, libri I-V, ed. R.M. Ogilvie, Oxford 1974; oraz tłumaczenie według: Tytus Liwiusz, Dzieje Rzymu od założenia miasta, t. 1, tłum. A. Kościółek, Wrocław 1968, s. 33: „Słuchaj, Jowiszu! [...] Jeżeliby [naród rzymski] pierwszy złamał te warunki z decyzji publicznej, w złych zamiarach, wtedy ty, Jowiuszu, tak uderz naród rzymski, jak ja tego wieprza tu dzisiaj uderzę, a uderz tym silniej, im większą masz władzę i potęgę" (przyp. red.)]. Czymś innym był jednak lapis manalis [kamień manów], przechowywany w świątyni Marsa przed porta Capena, który w czasie utrzymującej się suszy był wożony po ulicach miasta [Rzymu] dla wywołania deszczu (L. Preller, H. Jordan, Römische mythologie, op. cit., t. 1, s. 354 i n.) - najwyraźniej było to pierwotne przedstawienie „powozu burzy”.

${ }^{71}$ K. Seifart, Sagen, Märchen, Schwänke und Gebräuche aus Stadt und Stift Hildesheim, t. 2, Göttingen 1854, s. 187; R. Andrée, Braunschweiger Volkskunde, Braunschweig 1901, s. 411; M. Roediger, Aus dem Sitzungs-Protokollen des Vereins 
prehistorycznych są poszukiwanymi amuletami noszonymi w woreczkach na szyi ${ }^{72}$.

Niemniej jednak wielkim błędem byłoby zakładać, że wyobrażenie pioruna można sprowadzić do meteorytu. Musiało się ono rozwinąć na długo przed obserwacjami meteorytów i skojarzeniem ich ze zjawiskiem burzy znalazło bowiem odzwierciedlenie w obrazach stworzonych bez żadnego odniesienia do rzeczywistości obserwowalnej zmysłami. O błysku pioruna myślano jako o straszliwej broni niebios, często właśnie jako o strzale: sycylijski chłop klnie się na piorun i błyskawicę, używając formuły tuoni e saette (sagittae) $)^{73}$ [tzn. „na grzmoty i strzały”]; krzemienne groty strzał nosi się jako małe pioruny dla ochrony przed złem (zob. przyp. nr 58). Nierzadko na pomnikach zakończenia pioruna mają dodatkowo kształt grotów strzał (zob. np. przypis 18). Także włócznia, którą na monetach bityńskich dzierży Zeus Strategos albo Strategios [Zeus Dowódca, Zeus Dowódczy], mogła pierwotnie być obrazem błyskawicy (il. 15).

Jednakże Grecy nie mogli zadowolić się tak prostymi obrazami, jakie wystarczały innym ludom. Bardzo wcześnie pojawiło się więc fundamentalne wyobrażenie o obustronności pioruna - było to mimowolne zastosowanie elementarnej dualności prawej i lewej strony, która została przeniesiona na otaczający świat i całą sferę boską ${ }^{74}$. Do opisania pioruna używano zwrotów:

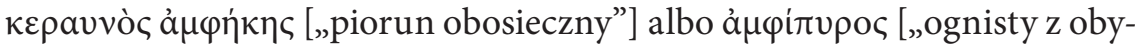
dwu stron"] czy też innych poetyckich określeń ${ }^{75}$. Bóg błyskawicy był początkowo czczony jako ‘ $\mu \varphi \iota \tau \rho \dot{\omega} \omega v$ - „przeszywający na wylot z obu stron”.

für Volkskunde, „Zeitschrift des Vereins für Volkskunde” 1899, Bd. 9, s. 226; V. Grohmann, Aberglaube und Gebräuche aus Böhmen und Mähren, Prag 1864, s. 37, nr 210. W H. Usener, Götternamen, s. 288, przyp. 13, gdzie wskazałem na przypadek zaobserwowany w Bonn.

72 Ant. A. de Nino, Usi Abruzzesi, t. 2, Firenze 1881, s. 36; G. Bellucci, La grandine nell' Umbria, Perugia 1903, s. 34.

73 S.A. Guastella, Padre Antonio, Ragusa 1885, s. 95.

74 Zob. H. Usener, Dreiheit; ein versuch mythologischer zahlenlehre, Bonn 1903, s. 335 i n.

75 Zob. idem, Göttliche Synonyme, „Rheinisches Museum für Philologie” 1898, Bd. 53, s. 336; idem, Dreiheit, op. cit., s. 344, przypis 4, por. także ả $\mu \varphi \imath \dot{\rho} \rho \omega \varphi$ $\varphi \lambda о \gamma \mu \tilde{\omega}$ („płomieniowi ognistemu na obu końcach”): Eurypides, Hekabe 473. 


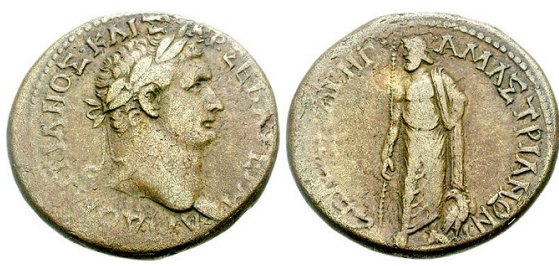

Il. 15. Domicjan, moneta brąowa (Amastris, Bitynia $i$ Pont), 84-96 r. Awers: AYT $\triangle O M I T I A N \Omega \Sigma$ KAILAP $\Sigma E B A$ ГEPM; głowa cesarza $w$ wieńcu laurowym $w$ prawo. Rewers:

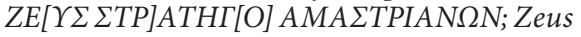
Strategos stojacy frontalnie, głowa zwrócona w lewo, prawa ręka oparta na włóczni; u jego stóp po prawej orzeł stojący $3 / 4 \mathrm{w}$ prawo z głowa zwrócona w lewo

Aktualizację tego wyobrażenia widać po tym, że na starszych przedstawieniach Zeus trzymał piorun w każdej z dłoni - tak jak bogini księżyca dwie pochodnie - na przykład Zeus "Оркıо [Horkios Strzegący Przysiąg] w buleuterionie w Olimpii czy też posąg Zeusa poświęcony przez wspólnotę arkadyjską przy wejściu na stadion w [okręgu świątynnym] Altis ${ }^{76}$. Stosownie do takich wyobrażeń piorun był powszechnie przedstawiany jako broń obosieczna. Grecy ukazywali go jako prosty, dwuzębny odcinek, z prawej i z lewej strony zakończony ostrym wierzchołkiem, z uchwytem pośrodku: tak pojawia się na przykład na fragmencie steli z Epidauros, na której widniał niegdyś dekret dotyczący proksenii ${ }^{77}$, jak również na wspomnianym wyżej reliefie z Mantui.

Obok tej próby ukazania pioruna mamy i inne, niewątpliwie starożytne, w których korzysta się z ówcześnie stosowanej broni. Najbardziej rozpowszechnioną bronią w rejonie Morza Śródziemnego był niegdyś labrys, topór bojowy o podwójnym ostrzu - bipennis. W epoce staroachajskiej, w której nie znano jeszcze wizerunków kultowych, podwójny topór był czczony jako święta istota (ostatecznie potwierdziły to wykopaliska w grocie diktejskiej [jaskini Dikte] i w pałacu królewskim na Krecie) ${ }^{78}$, dokładnie tak jak Macedończycy czcili Keraunosa. Kult w tym okresie dokonywał

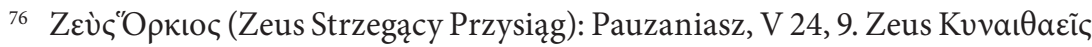
(Zeus Kynajtejski, którego posąg z gromem w dłoni podarowali dla Olimpii mieszkańcy Kynajty): Pauzaniasz, V 22, 1 por. VIII 19, 1. Bogini księżyca: H. Usener, Göttliche Synonyme, op. cit., s. 332.

77 P. Perdrizet, Parasima de villes sur des stèles de proxénie, „Bulletin de correspondance hellénique" 1896, Bd. 20, s. 556.

78 G. Karo, Altkretische Kultstätten, „Archiv für Religionswissenschaft” 1904, Bd. 7, s. 124-134, 123. 
się pod znakiem labrysu, tak jak chrześcijaństwo pod znakiem krzyża. W Karii ten stary symbol utrzymał się jeszcze w okresie późniejszym. Mylasa [współ. Milas] była centralnym ośrodkiem kultu Zeusa Stratiosa [Zeusa Wojskowego] dzierżącego labrys, nazywanego także starym imie-

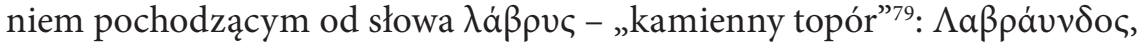
$\Lambda \alpha \beta \rho a u v \delta \varepsilon v \dot{~}$ [Labrayndos, Labrayndeus]. Na inskrypcjach wotywnych z Mylasy umieszczano niekiedy labrys pomiędzy imionami boga ${ }^{80}$. Równie często jak na monetach greckich piorun, na monetach z Afrodyzji (il. 16), Euromos i Mylasy (il. 17) oraz jako stempel do rewersów monet z Korakesionu w Cylicji pojawiał się labrys ${ }^{81}$. O tym, że nie chodziło tu o zwykłą broń, jak w przypadku labrysu w rękach Amazonek, lecz o przedstawienie błyskawicy, świadczy między innymi moneta ze Stratonikei, na rewersie której przedstawiony został orzeł na błyskawicy; orzeł zwrócony jest w prawą stronę, a przed nim znajduje się labrys ${ }^{82}$. Również w ogólnogreckiej świadomości dawny symbol z zamierzchłej starożytności przetrwał aż po epokę cesarstwa. Z zadziwiającą stałością wyspa Tenedos aż do I w. p.n.e. umieszczała na awersach swoich monet podwójną, męsko-żeńską głowę, a na rewersach labrys. Labrys utrzymywał się na rewersach jeszcze długo po tym, jak zmieniły się stemple do awersów. Dzięki Friedrichowi Imhoof-Blumerowi ${ }^{83}$ znamy okaz pewnej monety, na której obydwa skrzydła labrysu są podtrzymywane

79 Plutarch, Quaestiones Graecae 45; por. P. Kretschmer, Einleitung in die Geschichte der griechischen Sprache, Göttingen 1896, s. 404. Na temat Zeusa Labrayndosa zob. Herodot 5, 119; P. Foucart, Associations religieuses chez les Grecs, Paris 1873, s. 105 i n.; J.A. Overbeck, Griechische Kunstmythologie, t. 2, Leipzig 1871, s. $269 \mathrm{i} \mathrm{n.}$

${ }^{80}$ W. Judeich, Inschriften aus Karien, Mitteilungen des Deutschen Archäologischen Instituts, „Athenische Abteilung” 1890, Bd. 15, s. 259: raz po-

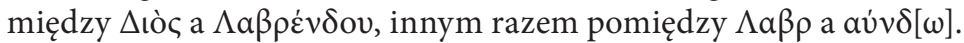

${ }^{81}$ Afrodyzja: F. Imhoof-Blumer, Monnaies grecques, Paris 1883, s. 305, nr 19; Euromos: ibidem, s. 310, nr 54; Mylasa: ibidem, s. 312, nr 70, 70a; Korakesion: „Revue international d'archéologie numismatique” 1902, vol. 5, tabl. XVIII, fig. 5; por. s. 253, nr 718.

82 F. Imhoof-Blumer, Monnaies grecques, op. cit., s. 315, nr 79. Por. G. Karo, „Altkretische Kultstätten”, s. 124 i n.

83 F. Imhoof-Blumer, Zur Münzkunde des Pontus, von Paphlagonien, Tenedos, Aiolis und Lesbos, „Zeitschrift für Numismatik” 1898, Bd. 20, s. 274 i n., tabl. X, fig. 9, 8. 

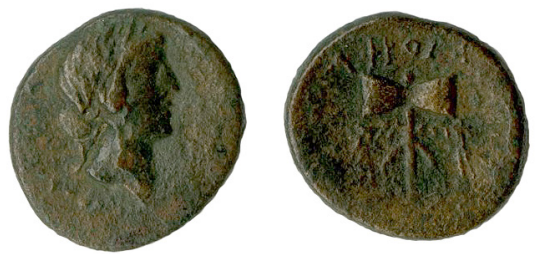

Il. 16. Moneta brazowa (Afrodyzjas, Karia), ok. 100-1 r. p.n.e. Awers: głowa Afrodyty $w$ wieńcu laurowym $w$ prawo. Rewers:

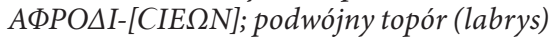
$z$ dwoma gałązami palmowymi skrzyżowanymi na jego trzonku
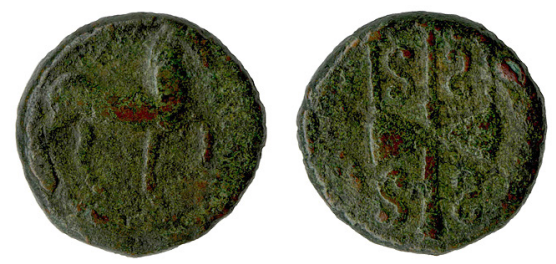

Il. 17. Moneta brązowa (Mylasa, Karia), ok. 200-30 r. p.n.e. Awers: koń galopująy w prawo. Rewers: ozdobny trójząb połaczony $z$ labrysem

przez podpórki, oraz jeszcze innej, na której za pomocą taenii do uchwytu topora przywiązana została amfora. Wymowa tych wizerunków nie budzi wątpliwości: na wyspie Tenedos labrys stanowił w świątyni przedmiot bezpośredniej czci. Jawi się nam to jako relikt epoki achajskiej, jeśli nie karyjskiej: nic dziwnego zatem, że później był już niezrozumiały i że dał

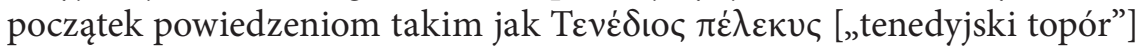

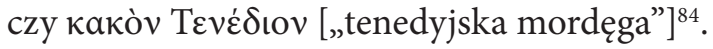

W północno-zachodniej Europie odpowiednikiem labrysu był młot w kształcie litery T, a więc także broń obustronna z uchwytem umieszczonym pośrodku. Jest to słynna broń skandynawskiego Thora, czyli niewątpliwie wyobrażenie błyskawicy, z tego właśnie względu w formie zminiaturyzowanej często noszone jako amulet ${ }^{85}$. Jego świętość manifestowała się w symbolicznym zastosowaniu w prawie zwyczajowym: w skandynawskim obrzędzie zaślubin panny młodej oraz w niemieckim zwyczaju obejmowania [ziemi]

84 Diogenianos (Gramatyk) 8, 58 Corpus Paroemiographorum Graecorum, t. 1, Göttingen 1851, s. 317 oraz Apostolios 10, 81; por. Arystoteles, Fr. 593.3 ed. W. Rose; H. Usener, Zwillingsbildung, Leipzig - Berlin 1900, s. 315-333 [= Kleine Schriften, t. 4, Leipzig 1913, s. 334-356], s. 328.

${ }^{85} \mathrm{H}$. Petersen, Om Nordboernes Gudedyrkelse og Gudetro. En antikvarisk undersøgelse, t. 1: Hedenold, Kopenhagen 1876, s. 75 i n.; por. s. 52 i n.; W. Golther, Handbuch der germanischen Mythologie, Leipzig 1895, s. 252. 
w posiadanie poprzez rzut młotem ${ }^{86}$. O powszechnym występowaniu tego wyobrażenia wśród Germanów świadczą używane do dziś przysłowiowe zwroty ${ }^{87}$, takie jak: dass dich der Hammer schlag („niech cię młot walnie” [por. polskie: „niech cię szlag trafi”]), dolnoniemieckie dat die de Hamer [„niech to szlag”] i ludowe określenia kamieni piorunowych (belemnitów) jako Donnerhammer („młoty pioruna”) czy Hämmerli („młoteczki”) ${ }^{88}$. Także celtyckie zabytki ${ }^{89}$ dowodzą, że bronią bóstwa uranicznego był cylindrycznie uformowany młot z uchwytem pośrodku. Odpowiednikiem etruskich demonów śmierci ukazywanych z młotem w ręku jest nasz Meister Hämmerli, znany z objaśnienia Ernsta Ludwiga Rochholza czart, uważany za bóstwo śmierci ${ }^{90}$.

Wspomnieliśmy już, że miejsce trafione piorunem Rzymianie określali mianem bidental. Starożytni uczeni wyjaśniają, że określenie to pochodzi od ofiary przeznaczonej do złożenia w tym miejscu - dwuzębnego jagnięcia (bidens). Jest to raczej próba wybrnięcia $\mathrm{z}$ kłopotu. Nie mam pojęcia, w jaki sposób od składania w ofierze ovis bidens [„dwuzębnej owcy”] miejsce

86 Zaślubiny panny młodej: J. Grimm, Deutsche Rechtsaltertümer, Göttingen 1828, s. 163, 431; W. Golther, Handbuch der germanischen Mythologie, s. 251 i n.; rzut młotem: J. Grimm, Deutsche Rechtsaltertümer, op. cit., s. 55 i n., s. 64.

87 J. Grimm, Deutsche Mythologie, Berlin 1854, s. 166; idem, Deutsches Wörterbuch [t. 1-16, Leipzig 1854-1960], t. 4, s. 315. Donnerhammer: E.L. Rochholz, Schweizer Sagen aus dem Aargau, Bd. 1, Aargau 1856, s. 386; Hämmerli: ibidem, t. 2, s. 205.

88 Również w polskim folklorze neolityczne siekierki krzemienne i skamieniałości belemnitów traktowane były jako „kamienie piorunowe” lub skamieniałe pioruny. Wierzono również w ich apotropaiczną moc; zob. K. Moszyński, Kultura ludowa Stowian, t. 2, cz. 1: Kultura duchowa, wyd. 2, Warszawa 1967, s. 734; M. Mazurkiewicz Kamień piorunowy w polszczyźnie i kulturze ludowej [szkic hasła do Słownika ludowych stereotypów językowych], [w:] Język a kultura, t. 1: Podstawowe pojęcia i problemy, red. J. Anusiewicz, J. Bartmiński, Wrocław 1991, s. 149-155 (przyp. red.).

89 A. Bertrand, Religion des Gaulois, Paris 1897, s. 318 i 354 (por. S. Reinach, Bronzes figurés de la Gaule romaine: description raisonnée du Musée de Saint-Germain en Laye Bronzes figurés, Paris 1894, s. 175).

90 E.L. Rochholz, Schweizer Sagen aus dem Aargau, t. 2, s. 204 i n. Przejście od boga piorunów, który obiera za mieszkanie ziemię, do boga śmierci obserwujemy już na obszarze hellenistycznym; zob. wyżej, przyp. 46. 
rażone piorunem miałoby wziąć nazwę bidental, a kapłani - sacerdotes bidentales. Uważam jednak za w pełni zrozumiałe, jeśli „dwuząb”, bidens, tj. harpun, był po prostu niegdyś rzymskim symbolem błyskawicy.

Niektóre z tych dualnych wyobrażeń, jeśli tylko było to możliwe, zostały szybko podporządkowane w swej formie troistości. Dla Rzymian błyskawica to fulmen trisculum [„,piorun potrójny”], u poetów zaś to trifida flamma [„płomień trójdzielny”] albo Iovis ignis tergeminus [„troisty ogień Jowisza"] ${ }^{91}$. Przekształceniu w formę troistą najłatwiej poddał się dwuzębny

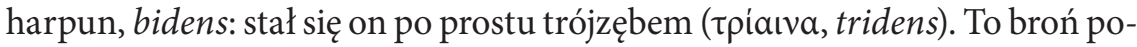
wszechnie przypisywana Posejdonowi, jak jednak wykazał Georg Loeschcke, w podobny sposób przedstawiano niekiedy także broń Zeusa. Natomiast pierwotna tożsamość trójzębu Posejdona z piorunem wydaje się wynikać z faktu, że w miejscu, gdzie według badań Nikolaosa Balanosa w Erechtejonie znajdował się ślad po trójzębie Posejdona, znajdował się hypetral, to znaczy otwór w dachu ${ }^{92}$, jakiego wymagano w przypadku miejsca uderzenia pioruna (zob. przyp. 27). Jeszcze Homer (Iliada XIV, 385n.) broń Posejdona nazywa

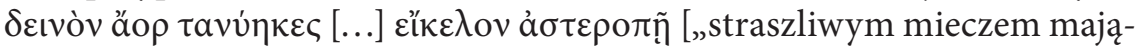
cym długie ostrze [...] podobnym do błyskawicy"93]. Wspólne dla Greków i przejęte przez Rzymian oraz innych Italików wyobrażenie pioruna wywodzi się od dawnego wyobrażenia pioruna jako linii prostej (zob. przyp. 60). Troistość można było nanieść na taką formę wyłącznie przez wyprowadzenie z głównej linii dwóch bocznych na kształt trójzęba. Takiemu rozgałęzieniu nadawano rozmaite układy. Często nie zadowalano się trzema zębami, ale przedstawiano ich pięć lub więcej: zawsze jednak zachowując liczbę trzy, np. gdy z pięciu promieni dwa położone najbardziej na zewnątrz wiązały się z promieniem głównym jako linią środkową, aby utworzyć trójdzielność. Często również dwa najbardziej zewnętrzne były tak wygięte, jakby tworzyły jakiś dwulistny kwiat ze słupkiem; na monetach z Elidy zadbano o to, by

91 Przykłady w: H. Usener, Dreiheit, op. cit., s. 189, przyp. 1.

92 Zob. W. Dörpfeld, Zum Erechtheion, „Mitteilungen des deutschen Archäologischen Instituts: athenische Abteilung” 1903, Bd. 28, s. 466 i n. Wskazówkę tę zawdzięczam memu studentowi, panu Lörmanowi.

93 Por. tłumaczenie K. Jeżewskiej, Iliada XIV, 384-386 (op. cit., s. 257): „Na czele Posejdon, co wstrząsa lądami, w dłoni potężny miecz ściskał, o długim ostrzu, straszliwy, do błyskawicy podobny" (przyp. red.). 
po jednej stronie wydawały się być ukształtowane na podobieństwo kwiatu (il. 18). Już dawno temu Karl Dilthey i Reinhardt Kekulé zwrócili uwagę na to, że błyskawicy można się dopatrzeć również w wyobrażeniu kwiatu, zwłaszcza liliii ${ }^{94}$.
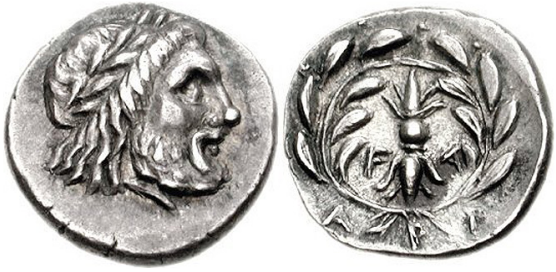

7.

Nie chcemy przeoczyć tutaj pewnej Il. 18. Srebrna hemidrachma (Olimpia, Elida), 271 r. p.n.e. Awers: głowa Zeusa w wieńcu laurowym w prawo. Rewers: $F$-A; piorun wewnątrz wieńca oliwnego; poniżej: A P I dodatkowej przesłanki. Prędkość, z jaką poruszał się piorun, skłaniała do wyobrażenia, że on w istocie lata:

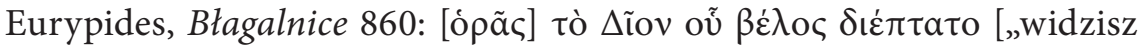

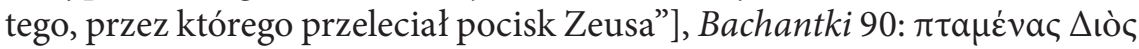
$\beta \rho o v \tau a \tilde{c}$ [„latające gromy Zeusa”]. Piorun musiał zatem mieć skrzydła:

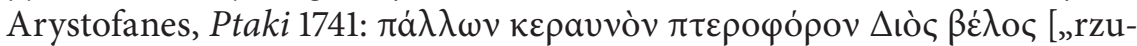
cając piorun, skrzydlaty pocisk Zeusa"], Sofokles, Edyp w Kolonie 1460: $\Delta$ iò

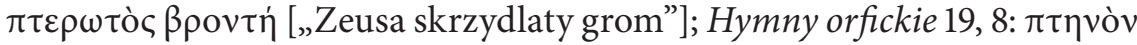
ő $\pi \lambda$ ov $\delta \varepsilon เ v o ́ v$ [„latający oręż straszliwy”]. I rzeczywiście, grecko-rzymskie pioruny były bardzo często wyposażone w skrzydła, najczęściej dwa, ale nierzadko nawet cztery ${ }^{95}$.

Powstały w ten sposób wizerunek - osobliwy i pełen sprzeczności - musi budzić zdziwienie: nieożywiona substancja, którą uważano za metaliczną, złączona została w jedno z częściami ciała istoty żywej. Oczywiście jest możliwe, że takie połączenie nastąpiło w sposób niezamierzony i miało charakter pierwotny: w takim wypadku droga rozwojowa, która zaczęła się od dodania skrzydeł, musiałaby jednak doprowadzić do dalszej rozbudowy

${ }^{94}$ Zob. R. Kekulé, Zeus Talleyrand, „Archäologische Zeitung” 1875, Bd. 32, s. 94.

95 Nie ma potrzeby przywoływać tu kolejnych przykładów obrazów i monet. Także na ołowianych tokenach piorun pojawia się z dwoma skrzydłami, jak w: A. Postolacca, Piombi inediti del nazionale museo numismatico di Atene, „Annali dell'Instituto di corrispondenza archeologica" 1868, Bd. 40, s. 296, nr 634; a z czterema skrzydłami - ibidem, nr 632 i n. 
w kierunku naturalnej istoty skrzydlatej, tym bardziej że według powszechnych wyobrażeń piorun był nosicielem boskiego ducha. Jest jednak równie prawdopodobne, że ta hybrydowa jedność pojawiała się w wyniku kompromisu pomiędzy dwoma całkiem różnymi wyobrażeniami: pioruna jako broni i pioruna jako ptaka. Krótko mówiąc, musimy uznać, że orzeł to kolejny grecko-rzymski obraz błyskawicy.

Orzeł, który według Homera „przez ciemne chmury” przedziera się na ziemię, aby spaść na swoją ofiarę, albo - jak powiada Babrios ${ }^{96}$ - swój łup ukrywa wysoko w chmurach ${ }^{97}$, jest z pewnością najtrafniejszym obrazem pioruna, jaki może zaoferować świat zwierząt. Za takim właśnie pomysłem przemawia wyjątkowe znaczenie orła, który był zarówno wzorem dla wyobrażeń bitych na antycznych monetach, jak i znakiem bojowym rzymskich legionów. Myślę jednak, że nie brakuje na to również bezpośrednich dowodów.

Wierzono i powiadano ${ }^{98}$, że orzeł jest jedynym spośród wszystkich ptaków, w którego nigdy nie trafia piorun. Wyobrażenie leżące u podstaw tego

96 Por. Babriosa Ezopowe bajki, tłum. Z. Węclewski, Poznań 1861 (przyp. red.).

97 Homer, Iliada XXII, 308-310 [por. wydanie: Homeri Ilias, ed. M.L. West,

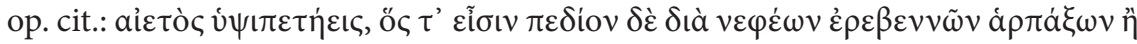

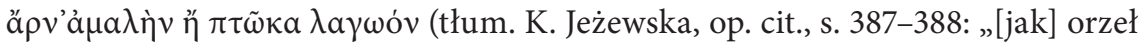
o locie podniebnym, gdy na równinę znienacka, drapieżny, z chmur mrocznych opada, by płochliwego zająca lub jagnię porwać bezsilne”) (przyp. red.)]; Babrios, Fab. 115, 8n. według Babrii Fabulae Aesopae, ed. G.C. Lewis, Oxford 1896, s. 123;

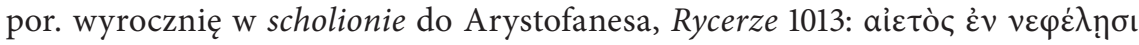

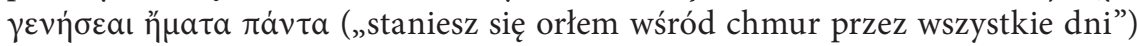

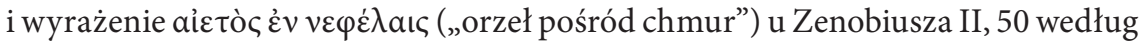
Corpus Paroemiographorum Graecorum, op. cit., t. 1, s. 45.

98 Pliniusz, Historia naturalna X, 4.15 [wydanie C. Plinii Secundi naturalis historiae libri XXXVII, hrsg. L. von Jan, K. Mayhoff, Bd. 1-6, Leipzig 1892-1909 (repr. Stuttgart 1967-2002) (przyp. red.)]: negant umquam solam hanc alitem fulmine exanimatam, ideo armigeram Iovis consuetudo iudicavit [(według tłumaczenia I. Mikołajczyka; Gajusz Pliniusz Sekundus, Historia Naturalna, t. 2, Toruń 2019, s. 345: „Powiadają, że jest to jedyny ptak, który nigdy nie został trafiony piorunem. Dlatego tradycja uznała, że orzeł przyniósł piorun Jowisza"; por. również tłumaczenie: K. Pliniusza Starszego Historyi Naturalnej ksiag XXXVII, tłum. J. Łukaszewicz, t. 4, Poznań 1845, s. 13 (przyp. red.)]; por. ibidem, 2, 56.146 [quoniam hoc solum 
mitu z zakresu historii naturalnej wywodzi się z pewnością ze sposobu wyciągania wniosków przez analogię, typowego dla myślenia ludowego, na który pragnę krótko zwrócić uwagę. Na Krecie, świętej wyspie Zeusa, znajdował się pewien potok, który miał tę właściwość, że każdy, kto się przezeń przeprawił - nawet podczas deszczu - pozostawał suchy ${ }^{99}$. To w nim miała zażyć oczyszczającej kąpieli Europa po obcowaniu z Zeusem. Ten potok był uważany za ziemski odpowiednik potoków niebiańskich, z których wypływa deszcz: kto w nim stoi, nie może zostać zmoczony przez deszcz, gdyż znajduje się ponad deszczem. Podobne wyobrażenie panowało na temat świętego, nieprzekraczalnego miejsca Zeusa Lykaiosa na górze Lykaion w Arkadii. Kto je przekroczył i się w nim znalazł, czy to człowiek, czy zwierzę, niezależnie od pory roku i dnia, nie rzucał cienia ${ }^{100}$. Kto przebywa w miejscu, które jest źródłem światła, wznosi się ponad cień, gdyż tylko to może rzucać cień, co znajduje się poniżej światła. Analogicznie: jeśli kamiennemu toporkowi przechowywanemu pod dachem przypisywano moc chronienia domu przed niebezpieczeństwem pioruna, to dlatego, że kamienny toporek uważano wprost za piorun, z czego wyciągano wniosek, że chroniony przez kamienny toporek dom już został wybrany przez boga błyskawic na miejsce zamieszkania, nie może zatem zostać wybrany po raz drugi. Tego, co już raz się dokonało, nawet sam bóg nie jest w stanie cofnąć. Według rozpowszechnionych wierzeń piorun nie trafia także w krzew leszczyny.

animal ex marinis non percutiat, sicut nec e volucribus aquilam, quae ob hoc armigera huius teli fingitur; tłum. I. Mikołajczyk, op. cit., t. 1, s. 131: „[o fokach:] spośród wszystkich zwierząt morskich piorun nie uderza tylko w nie" (przyp. red.)].

99 Kalimach Fr. 37 według Callimachea, hrsg. von O. Schneider, t. 2, Leipzig 1873,

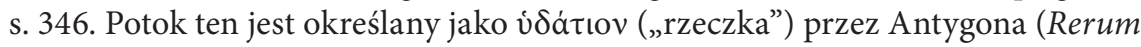
mirabilium collectio 163), zaś jako ỏxetó („kanał/potok”) u Sotiona (Excerpta IV) [por. Antygon z Karystos, Opowieści niezwykłe, tłum. E. Żybert, Wrocław 2014, s. 79: „Mówi też (Eudoksos), że ludzie siedzący podczas ulewy nad pewną rzeczułką na Krecie nie mokną. Według przekazów w jej nurtach obmyła się Europa po tym, jak połączyła się z Zeusem" (przyp. red.)]. Por. H. Usener, Religionsgeschichtliche Untersuchungen, Bd. 3: Die Sintfluthsagen untersucht, Bonn 1899, s. 199, przypis.

100 Teopomp, Fr. 272 FGH (Müller), t. 1, s. 324 [= FGrH (Jacoby) 115 F $343=$ Polibiusz XVI 12, 7]; por. również: Pauzaniasz VIII 38, 6; Plutarch, Quaestiones Graecae 39; zob. H. Usener, Religionsgeschichtliche Untersuchungen, vol. 3: Die Sintfluthsagen untersucht, s. 198 i n. 
Dlatego w Górnym Palatynacie podczas burzy wtykano w gzymsy okienne gałęzie leszczyny (z kolei w innych regionach wierzono, że w ten sam sposób można chronić się przed pożarem): czczono tym samym leszczynę jako wcielenie pioruna ${ }^{101}$. Widoczny w zaprezentowanych tu przykładach sposób myślenia był decydujący także w innych zwyczajach dotyczących obrony przed nieszczęściem. Gdy odniesiemy nasze obserwacje do mitu o orle, to staje się zrozumiałe, dlaczego nie może zostać trafiony piorunem, gdyż albo sam jest - jak powiada Pliniusz - niosącym piorun Jowisza (armigera Iovis [„nosicielem broni Jowisza”]), albo wręcz wyobrażeniem pioruna. Takiego wyjaśnienia nie dałoby się zanegować nawet wtedy, gdyby dało się udowodnić, że mit pojawił się po raz pierwszy dopiero w okresie hellenistycznym. W dalszych rozważaniach zobaczymy jednak, że dopiero w tak późnym okresie zaistniały po prostu odpowiednie uwarunkowania, ale samo prawdopodobieństwo przemawia za dużo starszą epoką. Także dla mieszkańców Indii okresu wedyjskiego, o czym przypomniał mi Ludwig Deubner, Agni [tj. bóg ognia/ogień] był „ognistym ptakiem” albo „potężnym sokołem (ewentualnie orłem), szybkim ptakiem o złotych skrzydłach"102. Wszelkie wątpliwości w tej kwestii rozwiewają odważne słowa poety, które Ajschylos zaczerpnął z głębokich pokładów ludowej intuicji ${ }^{103}$ :

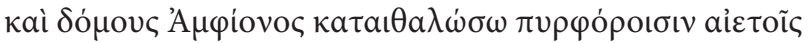
[a domostwo Amfiona do gruntu wypalę niosącymi ogień orłami].

Zeus grozi spaleniem pałacu Amfiona swoimi „niosącymi ogień orłami”.

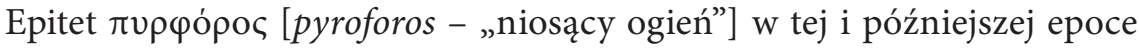

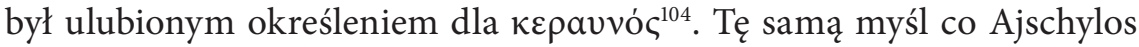

101 A. Kuhn, Die Herabkunft des Feuers und des Göttertranks. Ein Beitrag zur vergleichenden Mythologie der Indogermanen, Berlin 1859, s. 228 (2012 n.). Fakt ten wskazał mi pan doktor Deubner.

102 Ibidem, 28 i n. $\left(29^{2}\right)$.

${ }_{103}$ Ajschylos, Fr. 160 p. 33 N. powtórzone przez Arystofanesa, Ptaki 1247n.

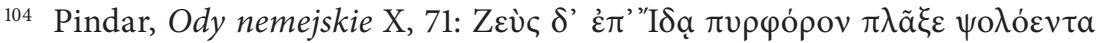

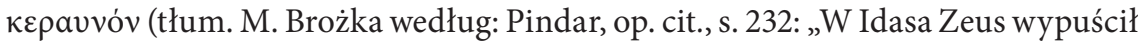

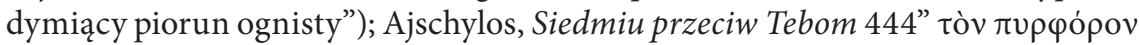

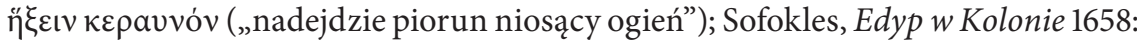

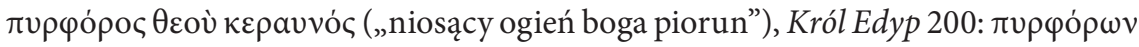


w nieco odmienny sposób podjął Eurypides w Błagalnicach 640, mówiąc o Kapaneusie:

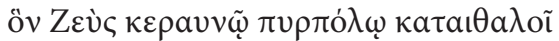

[oby go Zeus spopielił piorunem spalającym].

Rozumiemy teraz, dlaczego orzeł mógł, a nawet musiał się stać świętym zwierzęciem Zeusa ${ }^{105}$. Co prawda zbyt pochopnie byłoby uogólniać, że epokę kultu bóstw antropomorficznych poprzedzał etap kultu bóstw zoomorficznych, niemniej jednak bez wątpienia można odnaleźć ślady teriomorficznego wyobrażenia bogów, które zachowały się do czasów historycznych jako pozostałość wcześniejszej warstwy religijności. Zwierzęta, które napotykamy jako boskie symbole, należy bez wyjątku uznać za prastare formy przedstawień tych bogów. Niektóre posągi z Altis przedstawiały Zeusa trzymającego w lewej ręce orła, podczas gdy prawą ciskał on piorun $^{106}$. Takie przedstawienie pojawia się także na monetach z Messenii (il. 19). Gdzie indziej orzeł bywał umieszczany na wyciągniętej prawicy tronującego Zeusa - tak jest np. na monecie z Olous (Elounda) na Krecie i na najstarszych macedońskich emisjach z Egiptu (il. 20) ${ }^{107}$. Dopiero od czasów

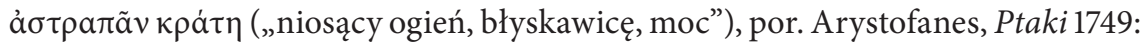

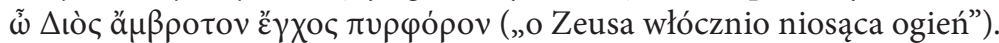

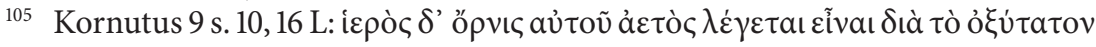

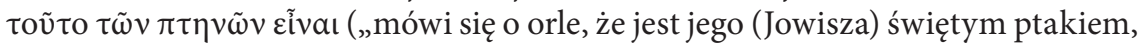
a to dlatego, ponieważ lata najszybciej"); już według Iliady XXIV, 311 Orzeł jest

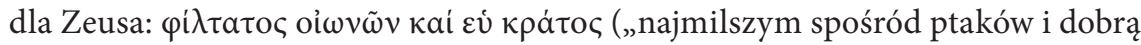

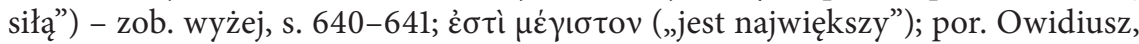
Metamorfozy XII, 561: divum gratissima regi („najdroższy królowi bogów”).

106 Pauzaniasz V 22, 5, 7; Monety z Messenii: zob. wyżej, O. Jahn, Giove Polieo in Atene (Nuove Memorie dell'Instituto di Corrispondenza Archeologica, t. 2), Lipsia 1865, s. 17 i n., tabl. I, fig. 3-6; por. J.A. Overbeck, Griechische Kunstmythologie, t. 1, op. cit., s. 23 i n., 12 i n. oraz K. Sittl, Der Adler und die Weltkugel als Attribute des Zeus in der griechischen und romïischen Kunst, „Jahrbücher für klassische Philologie" 1885, hrsg. von A. Fleckeisena, Supplementband XIV, s. 17 i n.

107 Olous: W. Wroth, Catalogue of the Greek Coins in the British Museum: Crete and the Aegean Islands, London 1886, tabl. XIV, fig. 12; por. s. 60, nr 1; J.N. Svoronos, Numismatique de la Crète ancienne, accompagnée de l'histoire, la géographie et la mythologie de l'ile, Première partie: Description des monnaies, histoire et géographie, 
Aleksandra Wielkiego orzeł bywał przedstawiany na monetach z piorunem w szponach ${ }^{108}$ : ma to miejsce już na najstarszych tetradrachmach Aleksandra (il. 21), następnie na monetach wybijanych przez Ptolemeusza I Sotera jako króla (il. 22), dosyć wcześnie takie wyobrażenie dotarło i do Italii, gdzie spotykamy je już na rzymskich monetach typu aes grave [wczesnych monetach z brązu] (il. 23a i 23b) i na monetach autonomicznych z Kapui (il. 24). Orzeł został więc nosicielem broni Zeusa ${ }^{109}$. Później zaś często przedstawiano go siedzącego na ziemi obok Zeusa ${ }^{110}$ jako jego strażnika lub ulubione zwierzę. Pomijając to ostatnie, żadne inne wyobrażenie orła nie przeczy jego ścisłym związkom z błyskawicą.

Począwszy od momentu, gdy dawny Keraunos - bóstwo pioruna - stał się Zeusem, wyobraźnia mitologiczna konsekwentnie także Zeusa, tak jak wcześniej Keraunosa, zaczęła przedstawiać pod postacią orła. Dobrze znana jest opowieść o tym, jak Zeus, porywając Ganimedesa, przeobraził się w orła. Wprawdzie wcześniejsi poeci, znając opowieść o tym porwaniu, nie

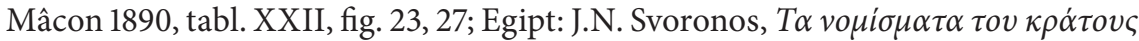

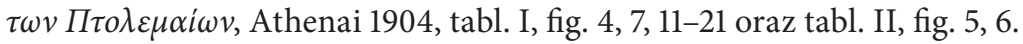

108 Aleksander: H. Gaebler, Die antiken Münzen Nord-griechenlands, Bd. 3: Makedonia und Paionia, Berlin 1906, tabl. XXXI, fig. 18, 23 (widziałem tablice

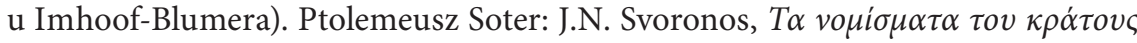

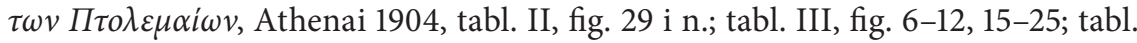
V, fig. 25, 26; tabl. VI, fig. 21-27; tabl. VIII-XIV, fig. 14, 24 itd. Rzym: E. Babelon, Description historique et chronologique des monnaies de la République romaine, vulgairement appelées monnaies consulaires, t. 1, Paris 1885, s. 4 oraz z czasów drugiej wojny punickiej: E. Babelon, op. cit., s. 25 i n, nr 29-31. Kapua: J. Friedländer, Die oskischen Münzen, Leipzig 1850, tabl. I, Capua nr 1. Por. E. Babelon, op. cit,, t. 1, nr 26. Por. K. Sittl, Der Adler und die Weltkugel..., op. cit., s. 12.

109 Wergiliusz, Eneida V, 255: Iovis armiger („niosący oręż Jowisza”), Owidiusz, Metamorfozy XV, 386: armigerumque Iovis („i niosący oręż Jowisza”); ibidem 10, 157n: nulla tamen alite verti dignatur nisi quae posset sua fulmina ferre („lecz w żadnego innego ptaka nie chciał zmienić się Jowisz, tylko w tego, który mógł nosić jego pioruny"); por. Pliniusz, Historia naturalna, II, 56.146; X, 4.15.

110 Na monecie z Tavium siedzący na tronie Zeus dzierży trójzębny piorun, po prawej i po lewej stronie siedzi w połowie wysokości orzeł; zob. W. Wroth, Catalogue of the Greek Coins in the British Museum: Galatia, Cappadocia, and Syria, London 1899, tabl. V, fig. 12, por. s. 27, nr 17. 

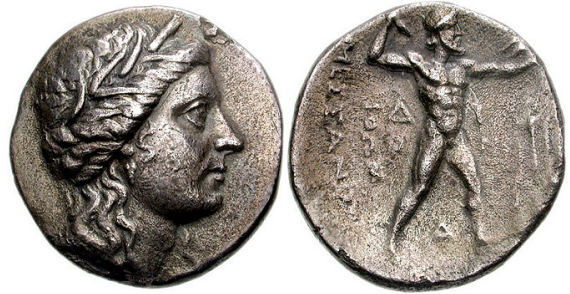

Il. 19. Srebrna tetradrachma (Messene, Messenia), ok. 183-182 r.p.n.e. Awers: głowa Demeter $w$ diademie $i$ wieńcu $z$ kłosów pszenicy w prawo, $w$ uchu perłowy kolczyk. Rewers: ME $\Sigma A N I \Omega N I \Theta \Omega M$ w lewy polu, $w$ centrum $\Delta-\mathrm{I} / \mathrm{O}-\mathrm{N}$; Zeus Ithomatas stojacy $w$ prawo, prawa ręka ciska piorun, $w$ lewej, wyciagiętej ręce trzyma orła; poniżej monogram $A ;$ w prawym polu trójnóg
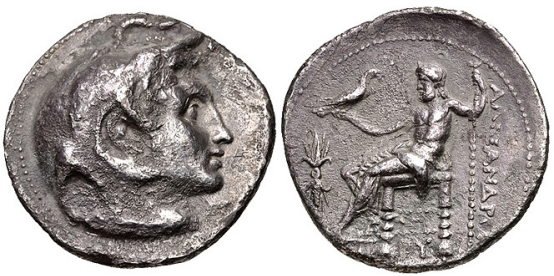

Il. 20. Ptolemeusz I Soter (jako satrapa), srebrna tetradrachma wybita $w$ imieniu Aleksandra IV (Memfis lub Aleksandria, Egipt), 317-311 r. p.n.e. Awers: głowa deifikowanego Aleksandra Wielkiego $w$ diademie $z$ rogiem Zeusa-Ammona, skalpie słonia $i$ aegis, $w$ prawo. Rewers: $A \Lambda E \Xi A N \triangle P O[Y]$ w prawym polu; Zeus Aëtophoros siedzacy $w$ lewo na tronie bez oparcia, w prawej, wyciagnietej ręce trzyma orła, lewa spoczywa na włóczni, stopy na podnóżku; w lewym polu piorun; pod tronem PY

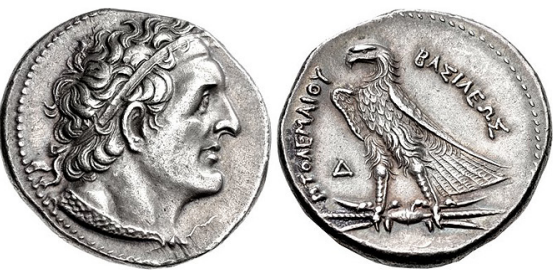

Il. 22. Ptolemeusz I Soter, srebrna tetradrachma (Aleksandria, Egipt), ok. 305285 r.p.n.e. Awers: głowa władcy w diademie $i$ aegis $w$ prawo, za uchem mała $\Delta$. Rewers:

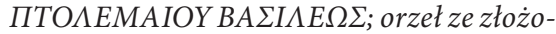
nymi skrzydłami stojący w lewo, trzymajacy w szponach piorun; $w$ lewym polu $\Delta$
11. 21. Aleksander Wielki, brazzowy hemiobol (Amfipolis, Macedonia), ok. 325-323/22 r. p.n.e. Awers: głowa młodzieńczego Heraklesa $w$ skalpie lwa $w$ prawo. Rewers: $A \Lambda E \Xi A-$ -NAPOY; orzeł ze złożonymi skrzydłami stojacy w prawo z głowa zwrócona w lewo, trzymający w szponach piorun; $w$ prawym polu $A$

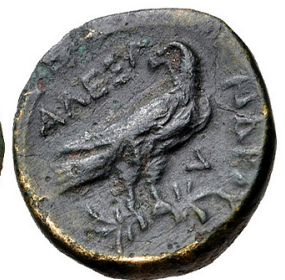



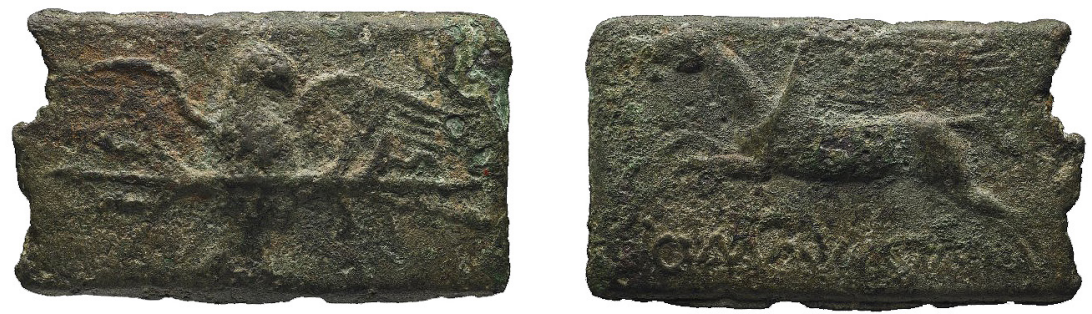

Il. 23a (awers) i 23b (rewers). Quincussis (aes signatum) (Rzym), ok. 280-250 r. p.n.e. Awers: orzet $z$ rozpostartymi skrzydłami ustawiony frontalnie, trzymajacy $w$ szponach piorun. Rewers: pegaz galopujacy w lewo; ponizej [R]OMANOM

spisują jej dokładniej - przykładem może być Homer, wedle którego (Iliada, XX, 234) Ganimedesa „porwali bogowie, aby był podczaszym Zeusa”"11 _ to nawet jeśli pierwsze wzmianki o przeobrażeniu się Zeusa w orła znamy dopiero $\mathrm{z}$ czasów hellenistycznych ${ }^{112}$, to i tak opowieść ta musiała powstać wcześniej, podobnie jak setki mitów, które aleksandryjscy poeci i badacze zaczerpnęli z miejscowej tradycji. Takie rozwiązanie wyda się nam bardziej prawdopodobne, gdy przywołamy drugi przykład przeobrażenia się bóstwa w orła: podanie, które - jak się wydaje - nie weszło w ogóle do literatury, ale zachowało znaczenie w skali lokalnej. Monety z Gortyny na Krecie zyskały sławę dzięki wyobrażeniu słynnego platana, o którym wierzono, że przestał zrzucać liście (oủ $\varphi v \lambda \lambda \circ \beta o \lambda \varepsilon \tilde{\imath}$ ), od kiedy Zeus zaślubił przy nim Europę (il. 25) ${ }^{113}$. Na pniu drzewa, rozłożona wśród gałęzi, tkwi Europa. Często towarzyszy jej orzeł. Wbrew rozpowszechnionej, znanej

111 Por. tłumaczenie K. Jeżewskiej, Iliada XX, 232-235 (op. cit., s. 357): „[...] Ganimedes do bogów podobny, co najpiękniejszy był z rodu całego ludzi śmiertelnych, więc go porwali bogowie na podczaszego Dzeusowi, dzięki urodzie, ażeby przebywał z nieśmiertelnymi" (przyp. red.).

112 Pierwsze świadectwo o przeobrażeniu w orła u Owidiusza, Metamorfozy X, 155 i n.; Wergiliusz, Eneida 5, 254 i n. jako porywacza wymienia jedynie orła. Zbyt krytycznie: C.G. Heyne, Ad Apollodori Bibliothecam observationes, Göttingen 1803. s. 294.

113 Teofrast, Historia plantarum I 9, 5 i inne; por. O. Jahn, Entführung der Europa auf antiken Kunstwerken (Denkschriften der Wiener Akademie XIX 1870), s. 25, przyp. 7. 
także na Krecie legendzie, według której Zeus uwiódł Europę, zjawiając się pod postacią byka, na całej serii tych monet ${ }^{114}$ orzeł ma pozę i zachowanie odpowiadające dokładnie postawie i zachowaniu łabędzia w znanej scenie obcowania z Ledą. Monety te nie pozostawiają cienia wątpliwości, że według opowieści z Gortyny, aby uwieść Europę, Zeus przemienił się właśnie w orła. Przeobrażenie się Zeusa w orła można zrozumieć jedynie pod warunkiem, że orzeł istotnie był formą wyobrażania Zeusa, a więc był z nim tożsamy. Jeśli teza ta wydaje się jeszcze wątpliwa, to należy zwrócić uwagę na tradycję miasta Sestos nad Hellespontem ${ }^{115}$. Był tam monument (opisywany jako heroon) „Zeusa i dziewicy”. Wiązała się z nim legenda: pewien orzeł, chowany od maleńkości przez młodą dziewczynę, okazywał swojej opiekunce wdzięczność na wszelkie sposoby, aż w końcu, gdy ta przedwcześnie zmarła, padł na jej stos pogrzebowy i dał się z spalić wraz z nią, a monument wzniesiono właśnie na pamiątkę tego wydarzenia. Sama legenda nie zachowała już ani postaci boskiej dziewicy, ani pamięci o roli Zeusa, którego imię przypisano do monumentu: wspomnienie o orle zachowało się zaś jedynie dzięki wieńczącemu monument przedstawieniu tego zwierzęcia. Mógłbym przytaczać dalsze przesłanki, że ta legenda wyraźnie mówiła o tożsamości Zeusa i orła, pora już jednak na tym poprzestać ${ }^{116}$.

114 O. Jahn, Die Entführung der Europa, tabl. IX, fig. h-k; por. s. 28 i n.; W. Wroth, Catalogue of the Greek Coins in the British Museum: Crete and the Aegean Islands, London 1886, tabl. X, fig. 7, 8; J.N. Svoronos, Numismatique de la Crète ancienne..., op. cit., tabl. XIV, fig. 16 - tabl. XV, fig. 8, szczególnie tabl. XV, fig. 1-7.

115 Pliniusz, Historia naturalna X, 6.18: Est percelebris apud Seston urbem aquilae gloria, eductam a virgine rettulisse gratiam, aves primo, mox deinde venatus adgerentem, defuncta postremo in rogum accensum eius iniecisse sese et simul conflagrasse. quam ob causam incolae quod vocant heroum in eo loco fecere appellatum Iovis et virginis, quoniam illi deo ales adscribitur („W mieście Sestos wielką czcią otacza się orła, który wychowany przez dziewicę odwdzięczał się jej, najpierw przynosząc ptaki, wkrótce potem inną zwierzynę. Wreszcie, że - kiedy ona zmarła - na rozpalony jej stos pogrzebowy orzeł się rzucił i razem z nią spłonął. Z tego powodu mieszkańcy zbudowali w tym miejscu heroion, który nazywają heroionem Jowisza i dziewicy, ponieważ temu bogu ów ptak jest przypisywany").

116 Można tu dodać na przykład dwa orły sprzed ołtarza Zeusa Lykejskiego (H. Usener, Dreiheit, op. cit., s. 199 u dołu), które znajdują swój odpowiednik $\mathrm{w}$ dwóch zwróconych do siebie orłach na małych srebrnych monetach Aleksandra 

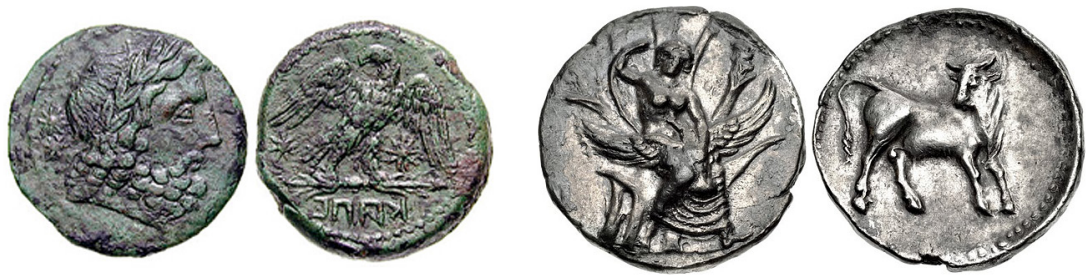

Il. 24. Sekstans (Kapua, Kampania), ok. 216Il. 25. Srebrny stater (Gortyna, Kreta), ok. 431-300 r. p.n.e. Awers: półnaga Europa z naszyjnikiem na szyi, siedzaca na pniu platanu $3 / 4$ w prawo, prawa ręka unosi welon nad głowa, lewa spoczywa na plecach znajdujacego się przed nia orła $z$ rozpostartymi skrzydami. Rewers: byk stojacy $w$ prawo, głowa zwrócona $w$ lewo

\section{8.}

Na przykładzie Keraunosa chciałem pokazać i ogólnie wyjaśnić pewne procesy rozwoju wyobrażenia religijnego i jego zobrazowania. Mogliśmy się zatem przekonać, że punktem wyjścia była tu zadziwiająco długo utrzymująca się w sferze kultu personifikacja (czyli uosobienie) konkretnych, uderzających w ziemię piorunów, czyli „bóstwo chwilowe”, któremu odpowiadał fetysz w postaci meteorytu. Stąd droga wiodła do wielorakości i gatunkowego charakteru wyobrażenia Keraunosa i Kerauniosa, aby następnie osiągnąć etap osobowego Zeusa (Jupitera, Jowisza) ciskającego gromami, którego kult przez osobliwy kompromis potrafił połączyć się ze starym wyobrażeniem „bóstwa chwilowego”. Udało się nam następnie ustalić, że proces jego obrazowania - niezależny od obserwacji zmysłowej - uwolnił się od mimowolnych inspiracji wizerunkowych, że pierwotnie ożywiony boski piorun musiał stać się bronią boga osobowego, tak jak orzeł świętym zwierzęciem Zeusa. Uzyskaliśmy w ten sposób wgląd w genezę i naturę pewnej symboliki religijnej, który może okazać się owocny i w innych przypadkach.

Wielkiego (F. Imhoof-Blumer, Monnaies grecques, Paris 1883, s. 129, nr 29-30; H. Gaebler, Die antiken Münzen Nord-griechenlands, Bd. 3: Makedonia und Paionia, Berlin 1906, tabl. XXXI, fig. 21) oraz na monetach miasta Afytos, pochodzących prawdopodobnie jeszcze z czasów Filipa II Macedońskiego (H. Gaebler, op. cit., tabl. XI, fig. 15, 16, 18). 
Wydaje mi się, że potrzebne było pokazanie na tym konkretnym przykładzie pewnych zjawisk panujących w świecie wyobrażeń religijnych. Przestarzałe i wypaczone opinie na ten temat są nadal popularne wśród nam współczesnych ${ }^{117}$. Pojedynczy uczony z danej dziedziny z trudem i rzadko zabiera się za oczyszczającą rewizję ogólnych pojęć i założeń, z którymi pracuje. Jest dla mnie w pełni zrozumiałe, że Georg Wissowa, któremu rozległa działalność nie pozostawia czasu na tego rodzaju badania, nie jest skłonny do rewizji własnych przekonań. Gdy jednak usiłuje on zwalczać niewygodne dla siebie poglądy, jak czyni to w ostatnio wydanych Esejach zebranych o historii religii i państwowości rzymskiej ${ }^{118}$, to powinien robić to z większą rozwagą i ostrożnością. Nie przepadam za polemiką i uważam, że jest czymś niegodnym, aby przeciwnikowi, którego głęboko szanuję, publicznie wytykać sprzeczności i błędy. Nie mogę jednak ukryć zdziwienia faktem, w jak niewielkim stopniu Wissowa przeczytał i zrozumiał książkę, której fundamentami chciał zachwiać.

Tłum. Piotr Napiwodzki Przekład przejrzał i redakcji naukowej dokonał: Sławomir Poloczek

\section{Źródła ilustracji}

Il. 1. Cohen, Description historique II, s. 338, nr 681; RIC III, s. 35, nr 80a; BMCRE IV, s. 34, nr 225, tabl. V, fig. 19; RSC II, s. 181, nr 681. @Classical Numismatic Group, LLC (www.cngcoins.com).

Il. 2. BMC Galatia, s. 269, nr 7-10, tabl. XXXII, fig. 5. (Classical Numismatic Group, LLC (www.cngcoins.com).

Il. 3. BMC Syria, s. 101, nr 7, tabl. XXVI, fig. 11; Babelon, Rois, s. 207, nr 1573, tabl. XXVIII, fig. 5. ( Classical Numismatic Group, LLC (www.cngcoins.com). Il. 4. BMC Galatia, s. 271, nr 22. (C) Classical Numismatic Group, LLC (www.cngcoins.com).

117 Tak na przykład w książce W. Golthera Handbuch der germanischen Mythologie na s. 243 czytamy: „Szczególnie u Germanów postać Gromowładnego oddzieliła się od postaci bóstwa uranicznego".

118 G. Wissowa, Gesammelte Abhandlungen zur römischen Religions- und Stadtgeschichte, München 1904 (przyp. red.). 
Il. 5. BMC Galatia, s. 276, nr 56, tabl. XXXIII, fig. 6. (T) The Trustees of the British Museum.

Il. 6. Imhoof-Blumer, Kleinasiat. Münzen II, s. 439, nr 3. (C) Classical Numismatic Group, LLC (www.cngcoins.com).

Il. 7. BMC Lycaonia, s. 72, nr 5, tabl. XII, fig. 13. (C) Classical Numismatic Group, LLC (www.cngcoins.com).

Il. 8. Mionnet, Descr. III, s. 577, nr 195; BMC Lycaonia, s. 73, nr 9, tabl. XIII, fig. 1. (C) Classical Numismatic Group, LLC (www.cngcoins.com).

Il. 9. Cohen, Description historique I, s. 419, nr 650 war.; RIC II, s. 312, nr 829; BMCRE III, s. 143, nr 703, tabl. XXIV, fig. 7. (C) Classical Numismatic Group, LLC (www.cngcoins.com).

Il. 10. Cohen, Description historique I, s. 462, nr 403; RIC II, s. 313, nr 833; BMCRE III, s. 144, nr 705, tabl. XXIV, fig. 11. (C) Classical Numismatic Group, LLC (www.cngcoins.com).

Il. 11. Cohen, Description historique I, s. 455, nr 316; RIC II, s. 119, nr 23; BMCRE II, s. 232, nr 51, tabl. XLV, fig. 10; RSC II, s. 58, nr 316. (Classical Numismatic Group, LLC (www.cngcoins.com).

Il. 12. Cohen, Description historique I, s. 519, nr 597; RIC II, s. 156, nr 24; BMCRE II, s. 303, nr 26, tabl. LIX, fig. 19; RSC II, s. 73, nr 597. (Classical Numismatic Group, LLC (www.cngcoins.com).

Il. 13. Cohen, Description historique II, s. 304, nr 345; RIC III, s. 43, nr 137; BMCRE IV, s. 77, nr 536; RSC II, s. 175, nr 345. CClassical Numismatic Group, LLC (www.cngcoins.com).

Il. 14. BMC Crete, s. 15, nr 9-11, tabl. III, fig. 17; Svoronos, Numism. de la Crète ancienne, s. 40, nr 34, tabl. III, fig. 11. @Classical Numismatic Group, LLC (www.cngcoins.com).

Il. 15. $R P C$ II, $\mathrm{nr} 712$, https://rpc.ashmus.ox.ac.uk/coins/2/712 [data dostępu: 14.01.2020]. (C) Classical Numismatic Group, LLC (www.cngcoins.com).

Il. 16. Imhoof-Blumer, Monnaies grecques, s. 305, nr 19; BMC Caria, s. 28, nr 20, tabl. V, fig. 10. $\odot$ The Trustees of the British Museum.

Il. 17. Imhoof-Blumer, Monnaies grecques, s. 312, nr 70; BMC Caria, s. 128, nr 7, tabl. XXI, fig. 13. (T) The Trustees of the British Museum.

Il. 18. BMC Peloponnesus, s. 72, nr 128. (C) Classical Numismatic Group, LLC (www. cngcoins.com).

Il. 19. Jahn, Giove Polieo in Atene, s. 17-18, tabl. I, fig. 3. (C)lassical Numismatic Group, LLC (www.cngcoins.com). 


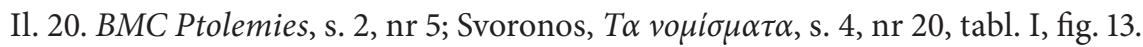
(C) Classical Numismatic Group, LLC (www.cngcoins.com).

Il. 21. Imhoof-Blumer, Monnaies grecques, s. 119, nr 37; Gaebler, Münzen Nordgriechenlands, s. 169, nr 5, tabl. XXXI, fig. 23. (Classical Numismatic Group, LLC (www.cngcoins.com).

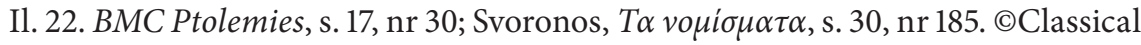
Numismatic Group, LLC (www.cngcoins.com).

Il. 23. Babelon, Monn. de la Républ. Rom. I, s. 6, nr 2 i s. 4-5, fig. 2; BMCRR I, s. 3, nr 2, tabl. III-IV; RRC I, s. 131, nr 4/1a. @ The Trustees of the British Museum.

Il. 24. Friedländer, Die oskischen Münzen, s. 11-12, nr 13, tabl. III, fig. 13. @ Classical Numismatic Group, LLC (www.cngcoins.com).

Il. 25. BMC Crete, s. 40, nr 29; Svoronos, Numism. de la Crète ancienne, s. 168, nr 83, tabl. XV, fig. 6. @Classical Numismatic Group, LLC (www.cngcoins.com).

\section{Wykaz zastosowanych skrótów}

Babelon, Monn. de la Républ. Rom. I - Babelon, E., Description historique et chronologique des monnaies de la République romaine, vulgairement appelées monnaies consulaires, t. I, Paris 1885.

Babelon, Rois - Babelon, E., Catalogue des monnaies grecques de la Bibliothèque nationale, Les rois de Syrie, d'Arménie, et de Commagène, Paris 1890.

BMC Caria - Head, B.V., Catalogue of the Greek Coins in the British Museum: Caria, Cos, Rhodes, etc., London 1897.

BMC Crete - Wroth, W., Catalogue of the Greek Coins in the British Museum: Crete and the Aegean Islands, London 1886.

BMC Galatia - Wroth, W., Catalogue of the Greek Coins in the British Museum: Galatia, Cappadocia, and Syria, London 1899.

BMC Lycaonia - Hill, G.F., Catalogue of the Greek Coins in the British Museum: Lycaonia, Isauria, and Cilicia, London 1900.

BMC Peloponnesus - Gardner, P., Catalogue of the Greek Coins in the British Museum: Peloponnesus (excluding Corinth), London 1887.

BMC Ptolemies - Poole, R.S., Catalogue of the Greek Coins in the British Museum: The Ptolemies, Kings of Egypt, London 1883.

BMCRE II - Mattingly, H., Carson, R.A.G., Coins of the Roman Empire in the British Museum, t. II: Vespasian to Domitian, London 1930.

BMCRE III - Mattingly, H., Carson, R.A.G., Coins of the Roman Empire in the British Museum, t. III: Nerva to Hadrian, London 1936. 
BMCRE IV - Mattingly, H., Carson, R.A.G., Coins of the Roman Empire in the British Museum, t. IV: Antoninus Pius to Commodus, London 1940.

BMCRR I - Grueber, H.A., Coins of the Roman Republic in the British Museum, t. I: Aes rude, aes signatum, aes grave, and coinage of Rome from BC 268, London 1910.

BMC Syria - Gardner, P., Catalogue of the Greek Coins in the British Museum: The Seleucid Kings of Syria, London 1878.

Cohen, Description historique I - Cohen, H., Description historique des monnaies frappées sous l'Empire Romain, communément appelées médailles impériales, $2^{\mathrm{e}}$ éd., t. I, Paris-Londres 1880.

Cohen, Description historique II - Cohen, H., Description historique des monnaies frappées sous l'Empire Romain, communément appelées médailles impériales, $2^{\mathrm{e}}$ éd., t. II, Paris-Londres 1882.

Friedländer, Die oskischen Münzen - Friedländer, J., Die oskischen Münzen, Leipzig 1850.

Gaebler, Münzen Nord-griechenlands - Gaebler, H., Die antiken Münzen Nordgriechenlands, Bd. 3.: Makedonia und Paionia, Berlin 1906.

Imhoof-Blumer, Kleinasiat. Münzen II - Imhoof-Blumer, F., Kleinasiatische Münzen, Bd. 2, Wien 1902.

Imhoof-Blumer, Monnaies grecques - Imhoof-Blumer, F., Monnaies grecques, Paris 1883.

Jahn, Giove Polieo in Atene - Jahn, O., Giove Polieo in Atene (Nuove Memorie dell'Instituto di Corrispondenza Archeologica, t. II), Lipsia 1865.

Mionnet, Descr. III - Mionnet, T.E., Description de médailles antiques, grecques et romaines, avec leur degré de rareté et leur estimation, t. III, Paris 1808.

RIC II - Mattingly, H., Sydenham, E., The Roman Imperial Coinage, t. II: Vespasian to Hadrian, London 1926.

RIC III - Mattingly, H., Sydenham, E., The Roman Imperial Coinage, t. III: Antoninus Pius to Commodus, London 1930.

RPC II - Burnett, A., Amandry, M., Carradice I., Roman Provincial Coinage, t. II: From Vespasian to Domitian (AD 69-96), London - Paris 1999.

RRC I - Crawford, M., Roman Republican Coinage, t. I, Cambridge 1974.

RSC II - Seaby, H.A., Roman Silver Coins, t. II: Tiberius to Commodus, $3^{\text {rd }}$ ed., London 1979.

Svoronos, Numism. de la Crète ancienne - Svoronos, J.N., Numismatique de la Crète ancienne, accompagnée de l'histoire, la géographie et la mythologie 
de l'ile, Première partie: Description des monnaies, histoire et géographie, Mâcon 1890.

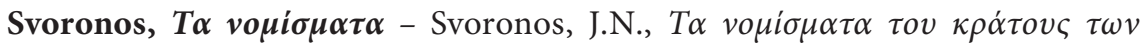

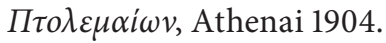

